\title{
Chemical, Physicochemical and Crystal - Chemical Aspects of Crystallization from Aqueous Solutions as a Method of Purification
}

\author{
Marek Smolik \\ Faculty of Chemistry, Silesian University of Technology, Gliwice \\ Poland
}

\section{Introduction}

This chapter is intended to discuss the effect of chemism of crystallizing and co-crystallizing substances (i.e., their chemical, physicochemical and crystal-chemical properties), as well as some other factors on efficiency of their separation and purification during crystallization from aqueous solutions.

There are three main aims of crystallization (Rojkowski \& Synowiec, 1991): creation of the solid phase, forming crystals, purification of substances.

While using crystallization for purification and separation of various substances, as well as for enrichment of trace amounts of new-found radioactive elements, it was established that (in addition to many others) chemical factors strongly affected the mentioned operations. Mechanisms of trace radioactive elements' co-crystallization and the significance of these factors on their enrichment efficiency were reviewed in some works (Przytycka, 1968; Niesmeanov, 1975).

The influence of factors determining the structures of salts of crystal ionic lattices, (salts considered as ionic coordination compounds) and their ability to isomorphous and isodimorphous mixing on their possibility to crystallization separation was thoroughly discussed by Balarew (1987). Whereas developments concerning inclusions of isomorphous impurities during crystallization from solutions were reviewed by Kirkova et al. (1998).

The discovered settlements were useful in the preliminary assessment of the effectivity of the crystallization method for purification of substances (Kirkova, 1994), for concentration microimpurities (Zolotov \& Kuzmin, 1982), for growing of single crystals of specific properties (Byrappa, et al., 1986; Demirskaya, et al. 1989), as well as in explanation of the genesis of some minerals (Borneman-Starinkevich, 1975).

In spite of development of solvent extraction and ionic exchange methods, crystallization is still a very attractive method of purification, particularly in the preparation of numerous high-purity inorganic substances (HPIS). There are two main reasons for that:

- for crystallization purification of a substance only the simplest reagents are necessary (like water or other solvents, sometimes salting out or complexing agends), which can be easily purified to the level suitable for HPIS and readily removed after crystallization; 
- $\quad$ in the case of many HPIS (especially crystalline preparations) crystallization is often the final stage of their preparation, which can be simply carried out without incidental contamination.

\section{Crystallization as a method of purification}

The crystallization should, in principle, yield very significant purification of a substance, but for the phenomenon of transport of accompanying impurities into the crystal, which may happen in the following ways presented in the simplified scheme below.

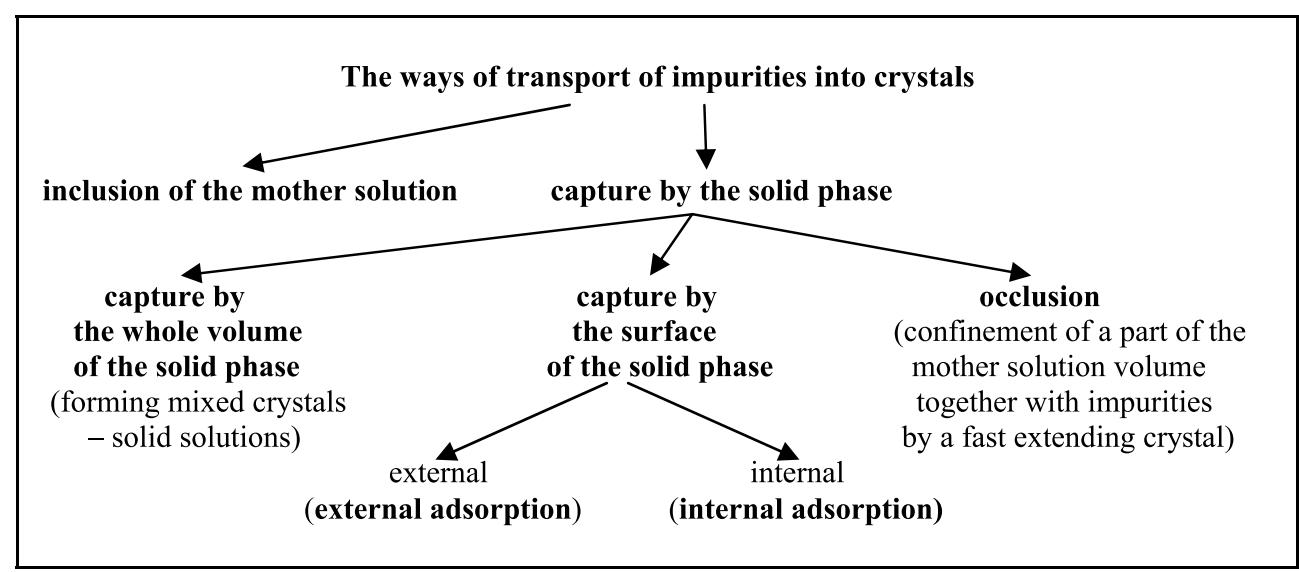

Although a suitable choice of crystallization conditions (supersaturation, rate of crystallization), as well as the ways of separation of crystals from mother solutions (filtration, washing) permits minimizing the capture of impurities derived from the inclusion of the mother solution, occlusion or external adsorption, it is impossible to restrict impurities originated from the capture by the whole volume of the solid phase or internal adsorption. ${ }^{1}$

The highest effect of purification may be expected when impurities are not captured by the solid phase of crystals but get into crystals as a result of the mother solution's residue, which cannot be removed by filtration ${ }^{2}$. In this boundary case the efficiency of crystal purification after its separation from the mother solution (without washing) is defined by the equation (Gorshtein, 1969):

$$
\frac{1}{K_{k}}=\frac{e_{k}^{\prime}}{e_{o}^{\prime}}=\frac{100-C_{k}}{C_{k}} \cdot \frac{C_{r}}{100-C_{r}} \cdot \frac{1}{1-\alpha}
$$

\footnotetext{
1 Internal adsorption takes place when microcomponents cannot form solid solutions with macrocomponent (Niesmieanov,1975)], it is a rather sparsely occurring phenomenon (Przytycka,1968).

2 During the crystallization without stirring or with not vigorous stirring, big, aggregated crystals (twins, intergrowth) are obtained. The presence of cavities on their surface obstructs the separation of mother solution from these crystals, which results in lowering their purity. Stirring during the crystallization at a considerable concentration of crystals causes rounding of crystals because of abrasion. Then large crystals adopt the form of spheres or ellipsoids, whose separation from mother solution by means of filtration is easier, which leads to higher purity of final product (Matusevich, 1961; Bamforth, 1965).
} 
where:

$\mathrm{K}_{\mathrm{k}}$ - crystal purification coefficient (multiplicity of lowering initial microcomponent contents in crystal)

$\mathrm{e}_{\mathrm{k}}^{\prime}$ - relative contents of a microcomponent in the crystal [ppm],

$\mathrm{e}_{\mathrm{o}}^{\prime}$ - initial relative contents of a microcomponent (before crystallization) [ppm],

$\mathrm{C}_{\mathrm{k}}$ - contents of the macrocomponent in the crystal [\%], (100- $\left.\mathrm{C}_{\mathrm{k}}\right)$ - crystal humidity [\%],

$\mathrm{C}_{\mathrm{r}}$ - contents of the macrocomponent in the mother solution, (its solubility) [\%],

$\alpha$ - degree of crystallization of the macrocomponent.

However, in reality, in numerous cases a microcomponent is captured by the solid phase, mainly by forming mixed crystals. Micro and macrocomponents form real mixed crystals (solid solutions) if they are isomorphous or isodimorphous.

\subsection{Co-crystallization coefficients}

\subsubsection{Homogeneous distribution coefficient $D_{2 / 1}$ (Henderson- Kraček, Chlopin)}

Homogeneous partition takes place in equilibrium conditions between the whole mass of a crystal and the mother solution, and is described by the Chlopin equation:

$$
\frac{n \rho_{s}}{m_{s}}=K_{X} \frac{\left(n_{o}-n\right) \rho_{r}}{m_{r}}
$$

where : $\mathrm{n}$ - number of moles of the microcomponent in a crystal, $\mathrm{n}_{\mathrm{o}}$ - the whole number of moles of the microcomponent in the system, $\mathrm{m}_{\mathrm{s}}$ - the mass of a crystal, $\mathrm{m}_{\mathrm{r}}$ - the mass of solution, $\rho_{\mathrm{s}}$ - density of crystal, $\rho_{\mathrm{r}}$ - density of solution, $\mathrm{K}_{\mathrm{X}}-$ Chlopin constant.

Taking into account that $\frac{n \rho_{s}}{m_{s}}=\frac{n}{\frac{m_{s}}{\rho_{s}}}=\frac{n}{V_{s}}=C_{s}$ as well as $\frac{\left(n_{o}-n\right) \rho_{r}}{m_{r}}=\frac{\left(n_{o}-n\right)}{\frac{m_{r}}{\rho_{r}}}=\frac{\left(n_{o}-n\right)}{V_{r}}=C_{r}$

where: $V_{s}$ and $V_{r}$ - volumes of the solid phase and the solution, $C_{s}$ and $C_{r}$ - concentration of a microcomponent in the solid phase and in the solution it is possible to obtain an equation, identical to the well-known Berthelot-Nernst equation describing the partition of a substance between two immiscible solvents $K_{x}=C_{s} / C_{r}$.

During the crystallization from the solution containing two components: macrocomponent (1) and microcomponent (2) the ratio of their partition coefficients defines the equilibrium co-crystallization coefficient:

$$
\mathrm{D}=\mathrm{D}_{2 / 1}=\frac{K_{2}}{K_{1}}=\frac{\left(\frac{C_{s}}{C_{r}}\right)_{2}}{\left(\frac{C_{s}}{C_{r}}\right)_{1}}=\frac{\left(\frac{C_{2}}{C_{1}}\right)_{s}}{\left(\frac{C_{2}}{C_{1}}\right)_{r}}=\frac{C_{2 s} \cdot C_{1 r}}{C_{1 s} \cdot C_{2 r}} .
$$

Substituting: $\mathrm{n}_{\mathrm{o}}$ and $\mathrm{n}$ - number of moles of microcomponent in the whole system and in the solid phase, and $z_{o}$ and $z$ - number of moles of macrocomponent in the whole system and in 
the solid phase into equation (3) and suitable rearranging, it is possible to obtain a more convenient Henderson \& Kraček equation (Niesmieanov, 1975):

$$
D_{2 / 1}=\frac{n\left(z_{o}-z\right)}{z\left(n_{o}-n\right)}
$$

Further transformation of this equation gives other, often used practical formulae (Smolik, 2004):

$$
D_{2 / 1}=\frac{\frac{n}{z}}{\frac{\left(n_{o}-n\right)}{\left(z_{o}-z\right)}}=\frac{e_{s}^{\prime}}{e_{r}^{\prime}}
$$

and

$$
D_{2 / 1}=\frac{\frac{n}{n_{o}}\left(\frac{z_{o}}{z_{o}}-\frac{z}{z_{o}}\right)}{\frac{z}{z_{o}}\left(\frac{n_{o}}{n_{o}}-\frac{n}{n_{o}}\right)}=\frac{\beta(1-\alpha)}{\alpha(1-\beta)}
$$

where $\alpha=z / z_{0}$ is the degree of crystallization of macrocomponent, $\beta=n / n_{0}$ is the degree of cocrystallization of microcomponent, $\mathrm{e}_{\mathrm{s}}^{\prime}$ and $\mathrm{e}_{\mathrm{r}}{ }_{\mathrm{r}}$ are relative concentrations of microcomponent in the solid phase and in the mother solution, respectively ([ppm] in relation to macrocomponent), $\mathrm{D}_{2 / 1}$ - homogeneous partition coefficient (co-crystallization coefficient).

\subsubsection{Heterogeneous (logarithmic) distribution coefficients $\lambda$ (Doerner-Hoskins)}

Logarithmic partition can take place if the equilibrium between the whole mass of crystal does not exist, but only between the surface layer of a crystal and solution. If $D_{2 / 1} \neq 1$, the concentration of microcomponent in the solution during the crystallization will be changing continuously. So the microcomponent will distribute in the crystal in a stratified manner ("onion" structure). This process for the elementary layer of the crystal may be described by the equation parallel to that of Henderson-Kraček: $\frac{d n}{d z}=\lambda \frac{\left(n_{o}-n\right)}{\left(z_{o}-z\right)}$,

where the meaning of $n_{0}, n, z_{0}, z$ is the same as previously described and $\lambda$ is the heterogeneous (logarithmic) partition coefficient. The integration of this expression yields the known equations (Doerner \& Hoskins, 1925):

$$
\ln \frac{n_{o}}{n_{o}-n}=\lambda \ln \frac{z_{o}}{z_{o}-z}
$$

or

$$
\lambda=\frac{\log (1-\beta)}{\log (1-\alpha)}
$$


Both homogeneous and heterogeneous partitions are boundary cases of distribution of the microcomponent between the solid phase and the mother solution. Experimental study involving which of both coefficients retains constant value with the increase of the degree of crystallization gives information on what partition is actually taking place.

\subsection{Homogeneous distribution coefficients $D_{2 / 1}$ as indicators of crystallization efficiency}

Homogeneous partition coefficients $D_{2 / 1}$ are a convenient measure of crystallization efficiency as a method of purification. In the case of homogeneous partition of microcomponent in the solid phase, the final result of purification (without washing) may be expressed by the formula (Gorshtein, 1969), derived on the basis of the balance of amounts of the microcomponent during the crystallization:

$$
\frac{1}{K_{k}}=\frac{e_{k}^{\prime}}{e_{o}^{\prime}}=\frac{D_{2 / 1}^{\prime}}{\alpha D_{2 / 1}^{\prime}+1-\alpha}+\frac{100-C_{k}}{C_{k}} \cdot \frac{C_{r}}{100-C_{r}} \cdot \frac{1-D_{2 / 1}^{\prime}}{\alpha D_{2 / 1}^{\prime}+1-\alpha}
$$

After careful washing of the crystals by pure, saturated solution of the macrocomponent, inclusions of the mother solution, as well as microcomponents adsorbed on the surface of the crystal, will be removed. The result of the purification in this case will be:

$$
\frac{1}{K_{k}}=\frac{e_{k(p)}^{\prime}}{e_{o}^{\prime}}=\frac{D_{2 / 1}}{\alpha D_{2 / 1}+1-\alpha}
$$

where: $\mathrm{K}_{\mathrm{K}-}$ multiplicity of lowering initial microcomponent contents $\left(\mathrm{e}_{0}^{\prime}, \mathrm{e}_{\mathrm{k}(\mathrm{p})}\right.$ - initial contents of microcomponent -[ppm] in crystal and in washed crystal after crystallization); $\mathrm{D}_{2 / 1}\left(\mathrm{D}_{2 / 1}^{\prime}\right)=$ $\mathrm{e}_{\mathrm{s}}\left(\mathrm{e}_{\mathrm{k}(\mathrm{p})}^{\prime}\right) / \mathrm{e}_{\mathrm{r}}^{\prime}\left(\mathrm{e}_{\mathrm{s}}^{\prime}\right.$ and $\mathrm{e}_{\mathrm{r}}^{\prime}$ - contents of micomponent - [ppm] in the solid phase and the mother solution); $\mathrm{D}_{2 / 1}$ - isomorphous co-crystallization coefficient of microcomponent, $\mathrm{D}_{2 / 1^{\prime}}$ adsorption-isomorphous co-crystallization coefficient of microcomponent; expression $\left(\mathrm{D}_{2 / 1}^{\prime}\right.$ $\left.\mathrm{D}_{2 / 1}\right) / \mathrm{D}_{2 / 1}^{\prime}$ qualifies a relative importance of adsorption in the capture of microcomponent by the solid phase (Gorshtein, 1969).

Knowing $\mathrm{D}_{2 / 1}\left(\mathrm{D}_{2 / 1}\right)$ and using the equations (9) and (10) it is possible to evaluate a number of crystallizations in the conditions of homogeneous partition of the microcomponent (at $\mathrm{D}_{2 / 1}\left(\mathrm{D}_{2 / 1^{\prime}}\right)=$ const.) necessary to achieve a desirable degree of purification of crystals. An example of such evaluation for $\mathrm{NiSO}_{4} \cdot 7 \mathrm{H}_{2} \mathrm{O}$ is presented in Table 1 .

\begin{tabular}{|c|c|c|c|}
\hline $\mathrm{D}_{2 / 1^{\prime}}$ & $\mathrm{D}_{2 / 1}$ & $\begin{array}{c}\text { Number of } \\
\text { crystallizations }(\mathrm{k})\end{array}$ & $\begin{array}{c}\text { The whole yield of purification } \\
\left(\mathrm{m}_{\mathrm{f}} / \mathrm{m}_{0}\right) \cdot 100 \%=\left(\alpha^{\mathrm{k}}\right) \cdot 100 \%\end{array}$ \\
\hline 0.75 & 0.75 & 15 & 0.003 \\
\hline 0.50 & 0.50 & 6 & 1.56 \\
\hline 0.25 & 0.25 & 3 & 12.5 \\
\hline 0.10 & 0.10 & 2 & 25.0 \\
\hline 0.05 & 0.05 & 1 & 50.0 \\
\hline
\end{tabular}

Table 1 . The number of $\mathrm{NiSO}_{4} 7 \mathrm{H}_{2} \mathrm{O}$ crystallizations necessary to achieve 10 -fold lowering of its initial contents of microcomponent for various levels of coefficient $\mathrm{D}_{2 / 1}\left(\mathrm{D}_{2 / 1^{\prime}}\right)\left(\right.$ Smolik, 2004), $\mathrm{C}_{\mathrm{k}}=98 \%, \mathrm{C}_{\mathrm{r}}=50 \%, \alpha=0,50(50 \%), \mathrm{m}_{0}\left(\mathrm{~m}_{\mathrm{f}}\right)$ - initial (after $\mathrm{k}$ crystallizations) mass of crystals 
The data presented in Table 1 show that the level of $D_{2 / 1}\left(D_{2 / 1}^{\prime}\right)$ is a very important parameter for the evaluation of crystallization efficiency as a method of purification, and therefore, its knowledge is significant in planning the utilization of crystallization in different stages of preparation of high purity substances.

\subsection{Practical and equilibrium $D_{2 / 1}$ coefficients}

However, crystallization processes are usually realized at non-equilibrium conditions and the obtained, in this case practical (effective), partition coefficients $\left(\mathrm{Dp}_{2 / 1}\right)$ depend on the ways in which the crystallization is carried out. This dependence may be presented by the following expression (Kirkova et al., 1996):

$$
\mathrm{Dp}_{2 / 1}=\mathrm{D}_{2 / 1} \Theta\left(\mathrm{T}, \mathrm{s}, \omega, \mathrm{m}_{2}, \mathrm{~m}_{\mathrm{j}} \kappa\right)
$$

where $\mathrm{D}_{2 / 1}$ - equilibrium co-crystallization coefficient, $\Theta$ - imbalance factor, which is a function of temperature $(\mathrm{T})$, supersaturation of the solution $(\varsigma)$, rate of stirring $(\omega)$, concentration of microcomponent $2\left(\mathrm{~m}_{2}\right)$, concentration of other microcomponents $\left(\mathrm{m}_{\mathrm{j}}\right)$ and other factors $(\kappa)$.

Since the equilibrium co-crystallization coefficient does not depend on crystallization conditions, it may be compared with various crystallization systems. Hence, it is important to trace the determination methods of such coefficients.

\subsection{Methods of determination of equilibrium distribution coefficients}

The possibility of achieving equilibrium homogeneous partition of microcomponents between solution and crystal solid phase was proved by Chlopin. Subsequent investigations in this area (Gorshtein, 1969; Chlopin, 1957; Zhelnin \& Gorshtein, 1971) elaboration upon several methods to accomplish equilibrium partition of microcomponents in the crystal, among which the method of isothermal decreasing of supersaturation and the method of long-time stirring of crushed crystals in their saturated solution are most often used.

\subsubsection{The method of isothermal decreasing of supersaturation}

It relies on cooling a saturated solution without stirring to the end temperature of crystallization (so that no crystal would appear) and after that on vigorous stirring at the constant end temperature until a complete removal of supersaturation takes place (usually for 3 - 360 h) (Zhelnin \& Gorshtein, 1971; Chlopin, 1957). An example of such determination of $\mathrm{D}_{2 / 1}$ eq is presented in Fig. 1

\subsubsection{The method of long-time stirring of crushed crystals in their saturated solution}

The equilibrium is reached starting either from the initial concentration ratio of a microcomponent in crystal and in solution exceeding the expected value of its equilibrium

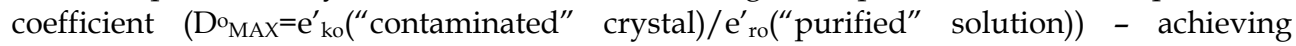
equilibrium "from above" or from this ratio lower than the expected value mentioned above $\left(\mathrm{D}^{\mathrm{o}}{ }_{\min }=\mathrm{e}^{\prime \prime}{ }_{\mathrm{ko}}\right.$ (" purified crystal)/ $\mathrm{e}_{\text {" } \mathrm{ro}}$ ("contaminated" solution) $)$ - achieving equilibrium "from below" (Fig. 2). 

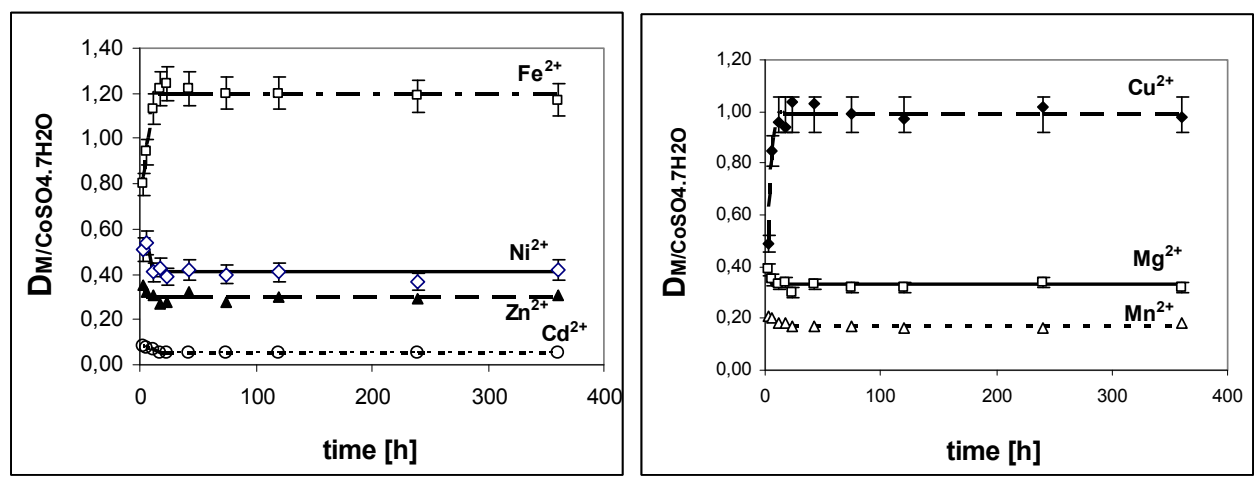

Fig. 1. Changes of co-crystallization coefficients, $\mathrm{D}_{2 / 1}$ of $\mathrm{M}^{2+}$ ions as the effect of isothermal levelling of supersaturation during the crystallization of $\mathrm{CoSO}_{4} \cdot 7 \mathrm{H}_{2} \mathrm{O}$ at $20{ }^{\circ} \mathrm{C}($ Smolik, 2003)

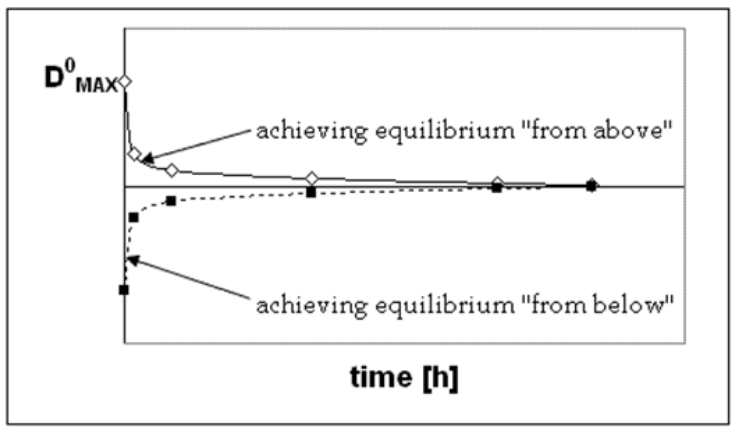

Fig. 2. The principle of the long-time stirring method for the determination of the equilibrium coefficients $D_{2 / 1}$ (Zhelnin \& Gorshtein, 1971; Chlopin, 1957)

When selecting values $\mathrm{D}^{\mathrm{o}}{ }_{\max }$ and $\mathrm{D}^{\mathrm{o}_{\text {min }}}$ the highest and the lowest values of $\mathrm{D}_{2 / 1}$ obtained during crystallization by the first method are usually taken into consideration. The experiments are carried out in the following way:

\begin{tabular}{|c|c|c|c|c|c|}
\hline \multirow{3}{*}{$\begin{array}{c}\text { Micro- } \\
\text { compo- } \\
\text { nent } \\
\mathrm{M}^{2+}\end{array}$} & \multirow{2}{*}{\multicolumn{2}{|c|}{ Initial $D_{2 / 1}$}} & \multicolumn{2}{|c|}{ Average $D_{2 / 1}$ after long time stirring } & \multirow{3}{*}{$\begin{array}{c}\text { Average } \\
\text { equilibrium } \mathrm{D}_{2 / 1} \\
\bar{D} \pm t_{\alpha} \frac{s}{\sqrt{n}}\end{array}$} \\
\hline & & & for $D^{o} \min$ & for $\mathrm{D}^{\circ} \mathrm{MAX}$ & \\
\hline & $\mathrm{D}_{\text {min }}$ & $\mathrm{D}^{\circ} \mathrm{MAX}$ & $\bar{D} \pm t_{\alpha} \frac{s}{\sqrt{n}}$ & $\bar{D} \pm t_{\alpha} \frac{s}{\sqrt{n}}$ & \\
\hline $\mathrm{Ni}^{2+}$ & 1.22 & 1.86 & $1.52 \pm 0.06$ & $1.62 \pm 0.09$ & $1.57 \pm 0.06$ \\
\hline $\mathrm{Cu}^{2+}$ & 0.08 & 0.22 & $0.14 \pm 0.02$ & $0.15 \pm 0.01$ & $0.14 \pm 0.01$ \\
\hline $\mathrm{Co}^{2+}$ & 0.77 & 1.89 & $1.18 \pm 0.09$ & $1.20 \pm 0.05$ & $1.19 \pm 0.04$ \\
\hline $\mathrm{Fe}^{2+}$ & 0.42 & 1.44 & $0.72 \pm 0.05$ & $0.79 \pm 0.06$ & $0.76 \pm 0.04$ \\
\hline $\mathrm{Mg}^{2+}$ & 0.16 & 3.47 & $1.33 \pm 0.12$ & $1.40 \pm 0.09$ & $1.36 \pm 0.07$ \\
\hline $\mathrm{Mn}^{2+}$ & 0.13 & 0.28 & $0.17 \pm 0.02$ & $0.20 \pm 0.02$ & $0.19 \pm 0.02$ \\
\hline
\end{tabular}

Table 2. Determination of equilibrium $\mathrm{D}_{2 / 1}$ coefficients of $\mathrm{M}^{2+}$ ions during the crystallization of $\mathrm{ZnSO}_{4} \cdot 7 \mathrm{H}_{2} \mathrm{O}$ at $23{ }^{\circ} \mathrm{C}$ (Smolik, 2000a) 
Crushed "contaminated" crystals (crushed to pass a $0.1 \mathrm{~mm}$ sieve $-\phi<0.1 \mathrm{~mm}$ ) are introduced into several beakers together with their saturated "purified" solution. Crushed "purified" crystals (crushed to pass a $0.1 \mathrm{~mm}$ sieve $-\phi<0.1 \mathrm{~mm}$ ) and their "contaminated" saturated solution are introduced to some other beakers. Contents of the beakers are stirred for $\sim 360 \mathrm{~h}$ with a magnetic stirrer at constant temperature (Table 2).

\section{Thermodynamic approach to the calculation of equilibrium $D_{2 / 1}$ coefficients}

The possibility of achieving a thermodynamic equilibrium during crystallization from solutions, as well as melts, as proved by Chlopin (1957), permits introducing a thermodynamic partition coefficient. Substituting concentrations of microcomponent (2) and macrocomponent (1) in equation (3) with their activities $\left(a_{1 s}, a_{2 s}, a_{1 r}, a_{2 r}\right)$ it is possible to obtain an expression for thermodynamic co-crystallization coefficient $\mathrm{D}_{2 / 1}$. (Kirkova et al., 1996; Ratner, 1933).

$$
D_{2 / 1}^{o}=\frac{a_{2 s} \cdot a_{1 r}}{a_{2 r} \cdot a_{1 s}}=\exp \left(-\frac{\Delta \mu_{2 / 1}^{o}}{R T}\right)
$$

$\Delta \mu^{\mathrm{o}_{2 / 1}}=\Delta \mu^{\mathrm{o}}{ }_{2}-\Delta \mu^{\mathrm{o}} 1$, where $\Delta \mu^{\mathrm{o}}{ }_{2}$ and $\Delta \mu^{\mathrm{o}}{ }_{1}$ are the changes of standard molar chemical potential of components (2) and (1) respectively during the transition from the liquid phase (r) into the solid phase (s). Two cases should be distinguished here: 1) substance (2) is not isomorphous with substance (1), i.e., it crystallizes in different crystal systems (different space groups); 2) substance (2) is isomorphous with substance (1).

In the first case the formation of mixed crystals by substance (2) with substance (1) may indicate the existence (besides the basic form [II] of microcomponent [2]) of a polymorphous form (I), metastable in suitable conditions, which is isomorphous with the crystal of the host: macrocomponent - substance (1). The transition of the substance (2) of the structure (II) into its metastable form of the structure (I) is connected with the increase of chemical potential:

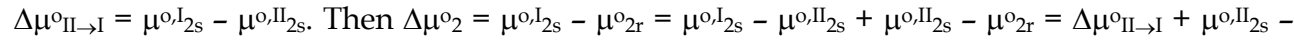
$\mu^{\mathrm{o}} 2 \mathrm{r}$, where $\Delta \mu_{\mathrm{II} \rightarrow \mathrm{I}}=\mu^{\mathrm{o}, \mathrm{I}_{2 \mathrm{~s}}}-\mu^{\mathrm{o}, \mathrm{II}}{ }_{2 \mathrm{~s}}$ - free partial molar enthalpy of phase transition II $\rightarrow \mathrm{I}$ of crystals of microcomponent (2) of structure (II) into the structure (I) proper to that of macrocomponent(1). Therefore (Smolik, 2004):

$$
\begin{aligned}
& D_{2, I I / 1, I}^{o}=\frac{\mathrm{a}_{1 \mathrm{r}} \mathrm{a}_{2 \mathrm{~s}}}{\mathrm{a}_{1 \mathrm{~s}} \mathrm{a}_{2 \mathrm{r}}}=\frac{\mathrm{a}_{1 \mathrm{r}} \mathrm{a}_{2 \mathrm{~s}}^{\mathrm{I}}}{\mathrm{a}_{1 \mathrm{~s}} \mathrm{a}_{2 \mathrm{r}}}=\exp \left(-\frac{\Delta \mu_{2}^{o}-\Delta \mu_{1}^{o}}{\mathrm{RT}}\right)=\exp \left(-\frac{\Delta \mu_{\mathrm{II} \rightarrow \mathrm{I}}^{\mathrm{o}}+\mu_{2 \mathrm{~s}}^{o, I I}-\mu_{2 \mathrm{r}}^{\mathrm{o}}+\mu_{1 \mathrm{r}}^{\mathrm{o}}-\mu_{1 \mathrm{~s}}^{\mathrm{o}}}{\mathrm{RT}}\right)= \\
& =\exp \left(\frac{\mu_{1 \mathrm{~s}}^{\mathrm{o}}-\mu_{1 \mathrm{r}}^{\mathrm{o}}}{\mathrm{RT}}\right) \cdot \exp \left(\frac{\mu_{2 r}^{o}-\mu_{2 s}^{o, I I}}{\mathrm{RT}}\right) \cdot \exp \left(-\frac{\Delta \mu_{I I \rightarrow I}^{o}}{R T}\right)=\frac{a_{1 r}^{o}}{a_{2 r}^{o}} \cdot \exp \left(-\frac{\Delta \mu_{I I \rightarrow I}^{o}}{R T}\right)
\end{aligned}
$$

If two double salts: $B_{b} E_{e} L_{l}(1)$ i $B_{b} E_{e} L_{l}$ (2) capable of forming solid solutions by the exchange of $\mathrm{B}$ ions into $\mathrm{B}^{\prime}$ ones (it is possible to exchange $\mathrm{E}$ ions into $\mathrm{E}^{\prime}$ or $\mathrm{L}$ into $\mathrm{L}^{\prime}$ ) dissociate into ions in aqueous solution according to the reaction:

$$
\mathrm{B}_{\mathrm{b}} \mathrm{E}_{\mathrm{e}} \mathrm{L}_{\mathrm{l}} \leftrightarrows \mathrm{bB}^{(\mathrm{z} 1)++} \mathrm{eE}^{(\mathrm{z} 2)++}+\mathrm{lL}(\mathrm{z} 3)-
$$

and 


$$
\mathrm{B}^{\prime}{ }_{\mathrm{b}} \mathrm{E}_{\mathrm{e}} \mathrm{L}_{\mathrm{l}} \leftrightarrows \mathrm{bB}^{\prime}(\mathrm{z} 1)++\mathrm{eE}(\mathrm{z} 2)++\mathrm{lL}(\mathrm{z} 3)-
$$

(obviously: $b z_{1}+e z_{2}-l z_{3}=0$ ) the following general formula may be derived for thermodynamic co-crystallization coefficient $\mathrm{D}_{2 / 1}$ (Balarew, 1987; Smolik \& Kowalik, 2010):

$$
D_{2 / 1}=\left(\frac{x_{2} \cdot m_{1}}{x_{1} \cdot m_{2}}\right)=\left(\frac{m_{01} \cdot \gamma_{m 01}}{m_{02} \cdot \gamma_{m 02}}\right)^{\frac{v}{b}} \cdot\left(\frac{\gamma_{m 2}}{\gamma_{m 1}}\right)^{\frac{v}{b}} \cdot \frac{f_{1}}{f_{2}} \cdot \exp \left(-\frac{\Delta \mu_{I I \rightarrow I}^{o}}{b R T}\right)
$$

where: $\mathrm{m}_{01}\left(\mathrm{~m}_{02}\right), \gamma_{\mathrm{m} 01}\left(\gamma_{\mathrm{m} 02}\right)$ - molal solubility $([\mathrm{mol} / \mathrm{kg}])$ of the salt $\left.\mathrm{B}_{\mathrm{b}} \mathrm{E}_{\mathrm{e}} \mathrm{L}_{\mathrm{l}}\left(\mathrm{B}^{\prime}{ }_{\mathrm{b}} \mathrm{E}_{\mathrm{e}} \mathrm{L}_{\mathrm{l}}\right)\right)$ and mean molal activity coefficient of the salt $\mathrm{B}_{\mathrm{b}} \mathrm{E}_{\mathrm{e}} \mathrm{L}_{\mathrm{l}}\left(\mathrm{B}^{\prime}{ }_{\mathrm{b}} \mathrm{E}_{\mathrm{e}} \mathrm{L}_{\mathrm{l}}\right)$ in its binary saturated solution; $\mathrm{m}_{1}\left(\mathrm{~m}_{2}\right)$, $\gamma_{\mathrm{m} 1}\left(\gamma_{\mathrm{m} 2}\right)$ - molality and mean molal activity coefficient of the salt $\mathrm{B}_{\mathrm{b}} \mathrm{E}_{\mathrm{e}} \mathrm{L}_{\mathrm{l}}\left(\mathrm{B}_{\mathrm{b}}{ }_{\mathrm{b}} \mathrm{E}_{\mathrm{e}} \mathrm{L}_{\mathrm{l}}\right)$ in the ternary solution being in equilibrium with $\left.\mathrm{B}_{\mathrm{b}}\left(\mathrm{B}_{\mathrm{b}}^{\prime}\right) \mathrm{E}_{\mathrm{e}} \mathrm{L}_{\mathrm{l}}\right)$ solid solution; $\mathrm{x}_{1}\left(\mathrm{x}_{2}\right)$ - mole fraction of $\mathrm{B}\left(\mathrm{B}^{\prime}\right)$ ion and $f_{1}\left(f_{2}\right)$ - activity coefficient of ion $\mathrm{B}\left(\mathrm{B}^{\prime}\right)$ in this solid solution; $\Delta \mu^{\mathrm{o}} \mathrm{II} \rightarrow \mathrm{I}$ - the partial molar Gibbs free energy of the phase transition of the salt $\mathrm{B}_{\mathrm{b}} \mathrm{E}_{\mathrm{e}} \mathrm{L}_{\mathrm{l}}$ from its structure (II) into the structure (I) of the salt $\mathrm{B}_{\mathrm{b}} \mathrm{E}_{\mathrm{e}} \mathrm{L}_{\mathrm{l}}, v=\mathrm{b}+\mathrm{e}+\mathrm{l}, \mathrm{R}$ - gas constant, $\mathrm{T}$ - temperature [K]

In the other case involving isomorphous substances (1) and (2) $\Delta \mu^{\mathrm{o}} \rightarrow \mathrm{I}=0$. Hence:

$$
D_{2 / 1}=\left(\frac{m_{01} \cdot \gamma_{m 01}}{m_{02} \cdot \gamma_{m 02}}\right)^{\frac{v}{b}} \cdot\left(\frac{\gamma_{m 2}}{\gamma_{m 1}}\right)^{\frac{v}{b}} \cdot \frac{f_{1}}{f_{2}}
$$

Equations (14) and (15) should, in principle, permit calculating exactly the equilibrium partition coefficient $\mathrm{D}_{2 / 1}$, if molal solubilities and all activity coefficients (in the aqueous and the solid phases), as well as the partial molar Gibbs free energy of the phase transition, were known. However, these data (except for molal solubilities) are rarely available. In contrast to mean molal activity coefficients in binary saturated solutions $\left(\gamma_{\mathrm{m} 01}, \gamma_{\mathrm{m} 02}\right)$, as well as those in the ternary solution being in equilibrium with $\left.B_{b}\left(B^{\prime}{ }_{b}\right) E_{e} L_{1}\right)$ solid solution $\left(\gamma_{m 1}, \gamma_{m 2}\right)$ which are sometimes directly accessible or calculable by means of Pitzer equations, activity coefficients in the solid solution $\left(f_{1}, f_{2}\right)$, as well as the partial molar free energy of the phase transition, are generally unknown (except for very rare individual cases of crystallization systems: macrocomponent(1) - microcomponent(2)).

The attempts to estimate $D_{2 / 1}$ coefficients by means of simplified equations (taking into account only activity coefficients in the liquid phase) are connected with huge errors, which proves that they result from the lack of the activity coefficients in the solid solution $\left(f_{1}, f_{2}\right)$ as well as the partial molar Gibbs free energy of the phase transition $\Delta \mu^{\mathrm{o}} \mathrm{II \rightarrow I}($ Smolik, 2004).

$$
\frac{\Delta[\%]}{100}=\frac{\left|D_{\text {exp. }}-D_{\text {cal. }}\right|}{D_{\text {exp. }}}=\left|1-\frac{D_{\text {cal. }}}{D_{\text {exp. }}}\right|=\left|1-\frac{f_{2}}{f_{1}} \cdot \exp \left(\frac{\Delta \mu_{I I \rightarrow I}^{0}}{b R T}\right)\right|
$$

In the case where coefficients $\mathrm{D}_{2 / 1}$ are independent of mixed crystal composition, the ratio $f_{2} / f_{1}$ remains constant (Balarew, 1987). Assuming the regular solution approximation this ratio may be expressed by the following equation:

$$
\frac{f_{1}}{f_{2}}=\exp \left(\frac{\Delta \overline{H_{1}}-\Delta \overline{H_{2}}}{R T}\right)
$$


where $\Delta \bar{H}_{1}-\Delta \bar{H}_{2}$ is the difference in the partial molar enthalpies of mixing.

According to Balarew (1987) this is the result of the difference in coordination environment around the two substituting ions, affected by ionic size differences $(\Delta \mathrm{r} / \mathrm{r})$, metal - ligand bond energy differences $(\Delta \varepsilon)$ with respect to the enthalpy of mixing (Urusov, 1977), as well as the difference in the energy determined by the crystal field (in the case non Jahn-Teller ions):

$$
\Delta \bar{H}_{1}-\Delta \bar{H}_{2}=w_{1} \cdot f\left(\frac{\Delta r}{r}\right)+w_{2} \cdot \varphi(\Delta \varepsilon)+w_{3} \cdot \psi(\Delta s)+\ldots
$$

Hence:

$$
D_{2 / 1}=\left(\frac{c_{01} \cdot \gamma_{c 01}}{c_{02} \cdot \gamma_{c 02}}\right)^{\frac{v}{b}} \cdot\left(\frac{\gamma_{c 2}}{\gamma_{c 1}}\right)^{\frac{v}{b}} \cdot \exp \left(-\frac{\Delta \mu_{I I \rightarrow I}}{R T}\right) \cdot \exp \frac{w_{1} \cdot f\left(\frac{\Delta r}{r}\right)+w_{2} \cdot \varphi(\Delta \varepsilon)+w_{3} \cdot \psi(\Delta s)+\ldots}{b R T}
$$

where: $\mathrm{f}, \varphi, \psi, \ldots$ - functions sought for, $\mathrm{w}_{1}, \mathrm{w}_{2}, \mathrm{w}_{3}, \ldots-$ estimated coefficients.

To derive an equation for estimating $D_{2 / 1}$ by finding the functions (f, $\varphi, \psi, \ldots$ ) and coefficients $\left(w_{1}, w_{2}, w_{3}, \ldots\right)$, it is necessary to check how $D_{2 / 1}$ coefficients depend on various factors.

\section{The dependence of co-crystallization coefficients, $D_{2 / 1}$ on chemical, physicochemical and crystal-chemical properties of co-crystallizing salts and ions}

Equilibrium co-crystallization coefficients are determined in the conditions ensuring that they do not depend on hydrodynamic and kinetic conditions of crystallization. However, they are affected by several factors both "external" (in relation to the co-crystallizing substances) and "internal" (resulting from chemical, physicochemical and crystal-chemical properties of the co-crystallizing substances).

"External" factors have chemical characteristics (kind and composition of the solvent - the liquid phase, the presence of ions or other foreign substances, the presence of complexing agents, acidity $(\mathrm{pH})$ of solution, from which crystallization takes place) or non-chemical ones (e.g., temperature). "Internal" factors are presented in Table 3.

\begin{tabular}{|l|l|}
\hline \multicolumn{2}{|c|}{ Chemical, physicochemical and crystal-chemical properties of } \\
\hline \multicolumn{1}{|c|}{ Co-crystallizing salts } & \multicolumn{1}{c|}{ Co-crystallizing ions } \\
\hline Solubility in water $\left(\mathrm{m}_{0}\right)$ & Charge of cation \\
\hline Crystal system $(\mathrm{CS})$ & Geometrical factor (ionic radius) $(\mathrm{r})$ \\
\hline $\begin{array}{l}\text { Number of molecules } \\
\text { of crystallization water }(\mathrm{n})\end{array}$ & $\begin{array}{l}\text { Character of chemical bond } \\
\text { (electronegativity) }(\varepsilon)\end{array}$ \\
\hline Reciprocal solubility in the solid phase (Cs $\mathrm{MAX})$ & Electronic configuration \\
\hline \multirow{2}{*}{$\begin{array}{l}\text { The volume of one formal molecule } \\
\text { of salt }\left(\eta^{3}\right)\end{array}$} & Crystal field stabilization energy (CFSE) \\
\cline { 2 - 3 } & Cation hardness (h) \\
\hline
\end{tabular}

Table 3. Chemical, physicochemical and crystal-chemical properties of co-crystallizing salts and co-crystallizing ions 
To analyse the influence of the above mentioned factors on co-crystallization coefficients $\mathrm{D}_{2 / 1}$, it is convenient to use correlation coefficients $\left(\rho_{\mathrm{xy}}\right)$ in the case of the properties that can be formulated quantitatively. For other properties (qualitative), mean $\mathrm{D}_{2 / 1}$ values for salts revealing and not revealing may be compared. On the other hand, co-crystallization coefficients may be considered as a measure of mutual solubility of co-crystallizing salts in the solid phase. The famous Latin rule: "Similia similibus solvuntur" (similar substances will dissolve similar substances) may be useful in the prediction of this solubility and the evaluation of $\mathrm{D}_{2 / 1}$ level.

\subsection{Chemical, physicochemical and crystal-chemical properties of co-crystallizing salts}

\subsubsection{Solubility in water $\left(m_{0}\right)$}

This is the most important factor affecting $\mathrm{D}_{2 / 1}$ coefficients. For the co-crystallization of isomorphous salts $\left(\Delta \mu_{\mathrm{II} \rightarrow \mathrm{I}}=0\right)$ forming ideal solid and liquid solutions $\left.\left(\left(\gamma_{\mathrm{m} 01} / \gamma_{\mathrm{m} 02}\right)^{(v / b)} \cdot\left(\gamma_{\mathrm{m} 2} / \gamma_{\mathrm{m} 1}\right)^{(v / b)}\left(\mathrm{f}_{1} / \mathrm{f}_{2}\right)=1\right)\right)$ they are expressed by $\mathrm{D}_{2 / 1}=\left(\mathrm{m}_{01} / \mathrm{m}_{02}\right)^{v / b}$.

However, this equation is proved true only for non-numerous salts fulfilling the additivity rule (Balarew, 1987). This simplified equation is the basis of the Ruff rule (Ruff et al., 1928):

If $\mathrm{m}_{01}>\mathrm{m}_{02} \rightarrow\left(\mathrm{m}_{01} / \mathrm{m}_{02}\right)^{\mathrm{v} / \mathrm{b}}=\mathrm{D}_{2 / 1}>1$. (During crystallization of two components, the less soluble one grows rich in crystal).

As it can be seen in Table 4, despite its simplicity and obviousness, this qualitative rule is not always fulfilled.

\begin{tabular}{|c|c|c|}
\hline Kind of co-crystallizing salts & $\begin{array}{l}\text { Number of considered } \\
\text { crystallization systems }\end{array}$ & $\begin{array}{c}\text { Crystallization systems } \\
\text { fulfilling the Ruff rule [\%] }\end{array}$ \\
\hline $\mathrm{MSO}_{4} \cdot \mathrm{nH}_{2} \mathrm{O}$ & 100 & 62 \\
\hline $\mathrm{MCl}_{2} \cdot \mathrm{nH}_{2} \mathrm{O}$ & 23 & 74 \\
\hline $\mathrm{M}(\mathrm{HCOO})_{2} \cdot 2 \mathrm{H}_{2} \mathrm{O}$ & 37 & 95 \\
\hline Alums, M(III) & 9 & 100 \\
\hline $\mathrm{M}_{2} \mathrm{M}^{\mathrm{II}}\left(\mathrm{SO}_{4}\right)_{2} \cdot 6 \mathrm{H}_{2} \mathrm{O} \mathrm{M}(\mathrm{I}), \mathrm{M}(\mathrm{II})$ & 59 & 96 \\
\hline $\mathrm{M}_{2} \mathrm{SO}_{4}$ & 24 & 54 \\
\hline MX & 16 & 69 \\
\hline $\mathrm{MClO}_{3}, \mathrm{MClO}_{4}, \mathrm{MNO}_{3}, \mathrm{M}_{2} \mathrm{CrO}_{4}$ & 17 & 59 \\
\hline \multicolumn{2}{|l|}{ mean } & 72 \\
\hline
\end{tabular}

Table 4. The degree of fulfilling the Ruff rule in some crystallization systems: macrocomponent - microcomponent (Smolik, 2004)

Mean molal activity coefficients of some isomorphous double salts, forming ideal solid solutions $\left(\mathrm{MI}_{2} \mathrm{M}^{\mathrm{II}}\left(\mathrm{SO}_{4}\right)_{2} \cdot 6 \mathrm{H}_{2} \mathrm{O}\right.$ or $\left.\mathrm{M}^{\mathrm{I} M} \mathrm{M}^{\mathrm{III}}\left(\mathrm{SO}_{4}\right)_{2} \cdot 12 \mathrm{H}_{2} \mathrm{O}\right)$ in their binary saturated solutions are inversely proportional to the square root of their molal solubility (Hill et al., 1940). Therefore:

$$
D_{2 / 1}=\left(\frac{m_{01} \cdot \gamma_{m 01}}{m_{02} \cdot \gamma_{m 02}}\right)^{\frac{v}{b}}=\left(\frac{m_{01} \cdot \sqrt{m_{02}}}{m_{02} \cdot \sqrt{m_{01}}}\right)^{\frac{v}{b}}=\left(\frac{m_{01}}{m_{02}}\right)^{\frac{v}{2 b}}
$$


For double salt dissociating: $\mathrm{NiSO}_{4} \cdot \mathrm{MI}_{2} \mathrm{SO}_{4} \cdot 6 \mathrm{H}_{2} \mathrm{O} \leftrightarrows \mathrm{Ni}^{2+}+2 \mathrm{M}^{+}+2 \mathrm{SO}_{4}^{2-}+6 \mathrm{H}_{2} \mathrm{O} \quad(v=5)$, it is possible to obtain for $\mathrm{M}^{+}$ions $(b=2)$ : $\mathrm{D}_{2 / 1}=\left(\mathrm{m}_{01} / \mathrm{m}_{02}\right)^{1,25}$ (Fig. 3) and for $\mathrm{M}^{2+}$ ions $(b=1)$ : $\mathrm{D}_{2 / 1}=\left(\mathrm{m}_{01} / \mathrm{m}_{02}\right)^{2,5}$ (Fig 4).

However, for a similar, but simple salt $\left(\mathrm{NiSO}_{4} \cdot 7 \mathrm{H}_{2} \mathrm{O}\right)$, an analogous dependence does not exist (Fig. 5) ( $\rho_{x y}=0.201$ is insignificant).

This is because of the significant differences in the crystal system of proper sulfate hydrates, while all of the investigated double salts are isomorphous, of the same space group $\left(\mathrm{P}_{1} / \mathrm{a}\right)$ and of almost identical unit cell parameters $(a, b, c, \beta)$ (their relative standard deviations do not exceed $0.8 \%$ )

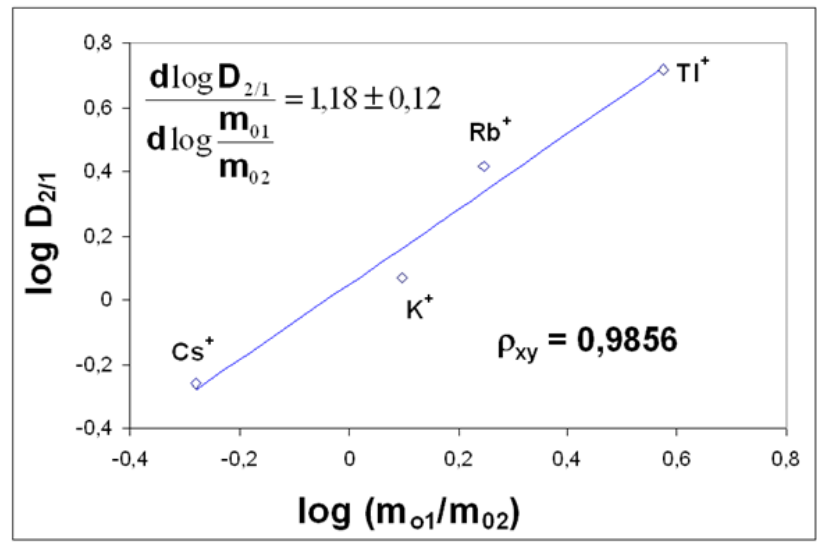

Fig. 3. The dependence of coefficients, $\mathrm{D}_{2 / 1}$ of co-crystalliztion of $\mathrm{Cs}^{+}, \mathrm{K}^{+}, \mathrm{Rb}^{+}$and $\mathrm{Tl}^{+}$with $\mathrm{NiSO}_{4} \cdot\left(\mathrm{NH}_{4}\right)_{2} \mathrm{SO}_{4} \cdot 6 \mathrm{H}_{2} \mathrm{O}$ on the molality of saturated solutions of suitable salts (Smolik, 1998a)

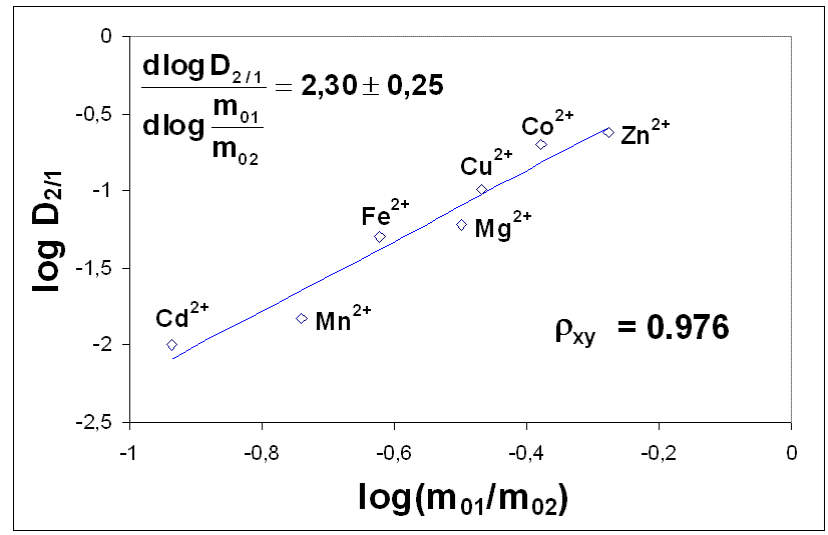

Fig. 4. The dependence of coefficients, $\mathrm{D}_{2 / 1}$ of co-crystallization of $\mathrm{Cd}^{2+}, \mathrm{Mn}^{2+}, \mathrm{Fe}^{2+}, \mathrm{Cu}^{2+}$, $\mathrm{Mg}^{2+}, \mathrm{Co}^{2+}$ and $\mathrm{Zn}^{2+}$ with $\mathrm{NiSO}_{4} \cdot\left(\mathrm{NH}_{4}\right)_{2} \mathrm{SO}_{4} \cdot 6 \mathrm{H}_{2} \mathrm{O}$ on the molality of saturated solutions of suitable salts (Smolik, 2001) 


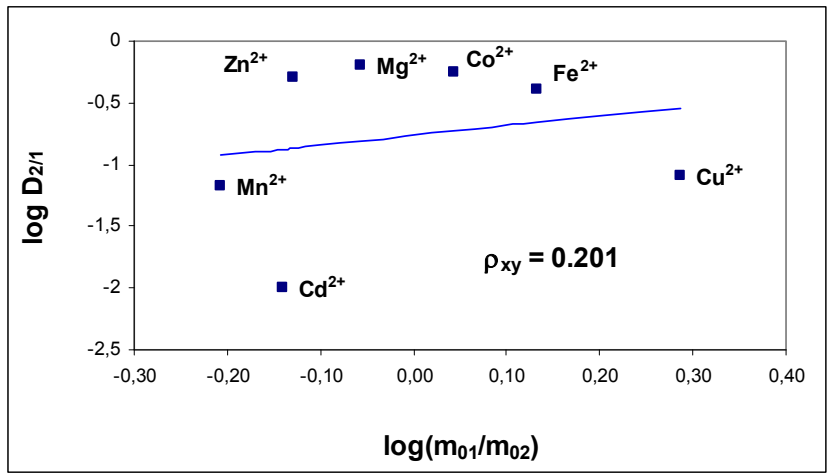

Fig. 5. The dependence of coefficients, $\mathrm{D}_{2 / 1}$ of co-crystallization of $\mathrm{Cd}^{2+}, \mathrm{Mn}^{2+}, \mathrm{Fe}^{2+}, \mathrm{Cu}^{2+}$, $\mathrm{Mg}^{2+}, \mathrm{Co}^{2+}$ and $\mathrm{Zn}^{2+}$ with $\mathrm{NiSO}_{4} \cdot 7 \mathrm{H}_{2} \mathrm{O}$ at $20{ }^{\circ} \mathrm{C}$ on the molality of saturated solutions of suitable sulfates (Smolik, 2000b]

\subsubsection{Crystal system (CS)}

The last three examples point to the crystal structure of co-crystallizing salts as a very important factor significantly affecting $\mathrm{D}_{2 / 1}$ coefficients. The dependence of similarity of the crystal structure of macro and microcomponent on mean co-crystallization coefficients in sulfate $\left(\mathrm{MSO}_{4} \mathrm{nH}_{2} \mathrm{O}\right)$ crystallization systems is presented in Fig. 6 and Fig. 7.

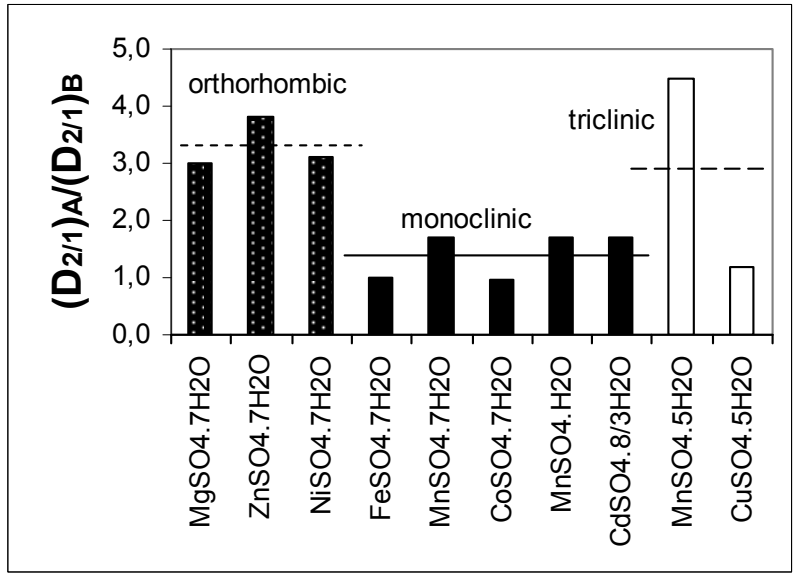

Fig. 6. The dependence of coefficients $\mathrm{D}_{2 / 1}$ on the similarity of the crystal system of macrocomponent $\left(\mathrm{CS}_{\mathrm{M}}\right)$ and microcomponent $\left(\mathrm{CS}_{\mathrm{m}}\right)\left(\mathrm{D}_{2 / 1}\right)_{\mathrm{A}}-$ mean $\mathrm{D}_{2 / 1}$ when $\left(\mathrm{CS}_{\mathrm{M}}\right)=\left(\mathrm{CS}_{\mathrm{m}}\right)$ $\left(\mathrm{D}_{2 / 1}\right)_{\mathrm{B}}-$ mean $\mathrm{D}_{2 / 1}$ when $\left(\mathrm{CS}_{\mathrm{M}}\right) \neq\left(\mathrm{CS}_{\mathrm{m}}\right)($ Smolik, 2002a, 2004)

As it can be seen, mean $\mathrm{D}_{2 / 1}$ coefficients of microcomponents whose hydrates belong to the same crystal system as the macrocomponent are $\sim 3$ times (for orthorhombic and triclinic macrocomponents) and $\sim 1.5$ times (for monoclinic macrocomponents) greater than those whose hydrates belong to a different crystal system than that of macrocomponent) (Fig. 6). 
The mean coefficients $\mathrm{D}_{2 / 1}$ of microcomponents belonging to the same crystal system as the macrocomponent are the highest, and they drop as the similarity of their crystal structure and that of the macrocomponent decreases (taking into account the following direction of the increase of crystal systems symmetry: triclinic<monoclinic<orthorhombic) (Fig. 7).

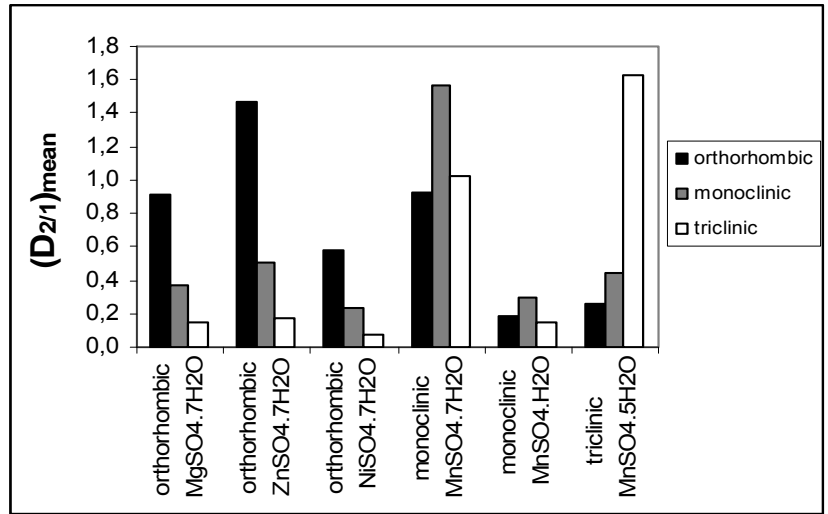

Fig. 7. The dependence of coefficients $\mathrm{D}_{2 / 1}$ on the similarity of crystal systems of macrocomponent $\left(\mathrm{CS}_{\mathrm{M}}\right)$ and microcomponent $\left(\mathrm{CS}_{\mathrm{m}}\right)\left(\mathrm{D}_{2 / 1}\right)_{\text {mean }}-$ mean $\mathrm{D}_{2 / 1}$ of microcomponents belonging to the same crystal system (Smolik, 2002a, 2004)

\subsubsection{Number of molecules of crystallization water $(n)$}

During the crystallization of hydrates the number of molecules of crystallization water (n) is an additional factor which may influence co-crystallization coefficients $\mathrm{D}_{2 / 1}$. It affects the coordination environment of the metal ion, which in the case of hepta or hexahydrates consists of only water molecules (the linkage of coordination octahedra in these crystals'

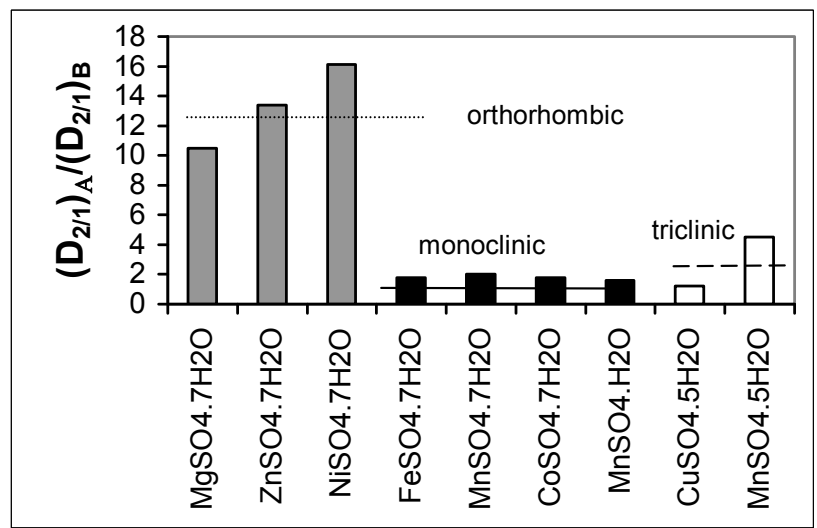

Fig. 8. $D_{2 / 1}=f\left(\Delta|n|=\left|n_{M}-n_{m}\right|\right) n_{M}\left(n_{m}\right)$ - number of molecules of crystallization water of macrocomponent (microcomponent) (Smolik, 2002a, 2004), $\left(\mathrm{D}_{2 / 1}\right)_{\mathrm{A}}-$ mean $\mathrm{D}_{2 / 1}$ when $|\Delta \mathrm{n}|=0$ $\left(\mathrm{D}_{2 / 1}\right)_{\mathrm{B}}-$ mean $\mathrm{D}_{2 / 1}$ when $|\Delta \mathrm{n}| \neq 0$ 
structures is determined by weak hydrogen bonds), but in lower hydrates oxygen atoms of polyatomic anions enter the coordination environment of the metal ions (causing the formation of chains, closed rings, planar or space networks by vertices-sharing coordination polyhedral) (Balarew, 1987). Generally, mean $\mathrm{D}_{2 / 1}$ values are higher the more similar are $\mathrm{n}$ values of macro and microcomponents (Fig. 8 and Fig. 9).

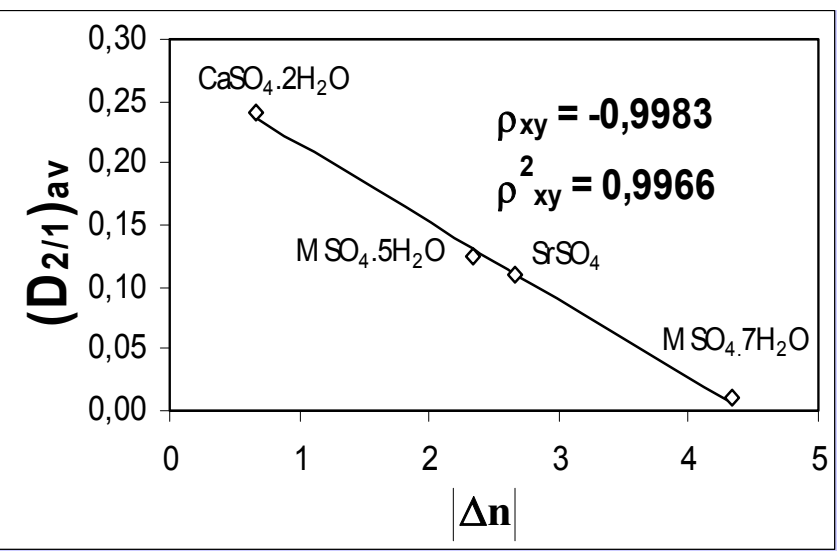

Fig. 9. $\left(\mathrm{D}_{2 / 1}\right)_{\mathrm{av}}=f\left(\Delta|\mathrm{n}|=\left|\mathrm{n}_{\mathrm{M}}-\mathrm{n}_{\mathrm{m}}\right|\right)$ during the crystallization of $\mathrm{CdSO}_{4} \cdot 8 / 3 \mathrm{H}_{2} \mathrm{O}$ at $20{ }^{\circ} \mathrm{C}$ (Smolik, 2002b, 2004), $\rho_{\mathrm{xy}}$ - correlation of $\left(\mathrm{D}_{2 / 1}\right)_{\text {av }}$ and $\Delta|\mathrm{n}|$

\subsubsection{Reciprocal solubility in the solid phase $C_{\text {MAX }}^{s}$}

It is known that the coefficients of co-crystallization of impurities are proportional to their solubilities in the solid phase in the case of crystallization of Ge and Si (Fisher, 1962), as well as several dozen molten metals (Vachobov et al., 1968). However, such regularity has not

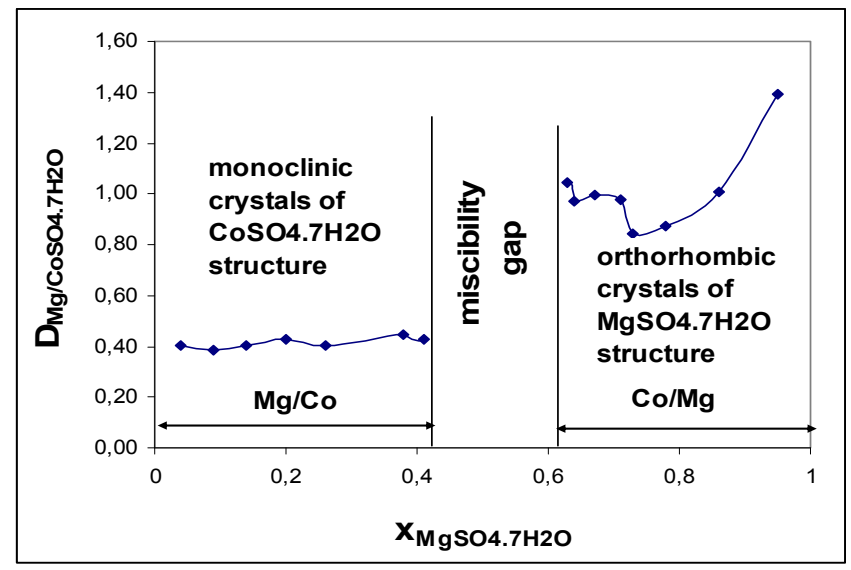

Fig. 10. The dependence of $\mathrm{D} \mathrm{Mg} / \mathrm{CoSO} 4.7 \mathrm{H} 2 \mathrm{O}$ on mole fraction of $\mathrm{MgSO}_{4} \cdot 7 \mathrm{H}_{2} \mathrm{O}$ in the solid phase (Oikova et al., 1976) ; $\mathrm{Mg} / \mathrm{Co}$ - solubility of $\mathrm{MgSO}_{4} \cdot 7 \mathrm{H}_{2} \mathrm{O}$ in $\mathrm{CoSO}_{4} \cdot 7 \mathrm{H}_{2} \mathrm{O}, \mathrm{Co} / \mathrm{Mg}$ solubility of $\mathrm{CoSO}_{4} \cdot 7 \mathrm{H}_{2} \mathrm{O}$ in $\mathrm{MgSO}_{4} \cdot 7 \mathrm{H}_{2} \mathrm{O}$ 
been found yet during the crystallization of salts from aqueous solutions. The term "solubility in the solid phase" is explained in Fig 10. It is the maximal concentration of a hydrate in another hydrate, which does not cause the change in its structure.

The effect of the solubility in the solid phase $\left(\mathrm{C}^{\mathrm{s}} \mathrm{MAX}\right)$ on $\mathrm{D}_{2 / 1}$ coefficients is presented in Table 5. As it can be seen in most analysed cases, $D_{2 / 1}$ is proportional to the maximal reciprocal solubility in the solid phase ( $\mathrm{C}_{\mathrm{MAX}}$.) which is proved by relatively high and significant correlation coefficients $\left(\rho_{\mathrm{xy}}\right)$, marked bold.

\begin{tabular}{|l|l|l|c|}
\hline No & \multicolumn{1}{|c|}{ Macrocomponent } & \multicolumn{1}{|c|}{ Microcomponents } & $\rho_{\mathrm{xy}}$ \\
\hline 1. & $\mathrm{MgSO}_{4} \cdot 7 \mathrm{H}_{2} \mathrm{O}$ & $\mathrm{Ni}^{2+}, \mathrm{Mn}^{2+}, \mathrm{Fe}^{2+}, \mathrm{Cu}^{2+}, \mathrm{Zn}^{2+}, \mathrm{Cd}^{2+}, \mathrm{Co}^{2+}$ & $\mathbf{0 . 7 6 3 5}$ \\
\hline 2. & $\mathrm{ZnSO}_{4} \cdot 7 \mathrm{H}_{2} \mathrm{O}$ & $\mathrm{Ni}^{2+}, \mathrm{Mn}^{2+}, \mathrm{Fe}^{2+}, \mathrm{Cu}^{2+}, \mathrm{Mg}^{2+}, \mathrm{Cd}^{2+}, \mathrm{Co}^{2+}$ & $\mathbf{0 . 8 6 0 8}$ \\
\hline 3. & $\mathrm{NiSO}_{4} \cdot 7 \mathrm{H}_{2} \mathrm{O}$ & $\mathrm{Zn}^{2+}, \mathrm{Fe}^{2+}, \mathrm{Cu}^{2+}, \mathrm{Mg}^{2+}, \mathrm{Cd}^{2+}, \mathrm{Co}^{2+}$ & $\mathbf{0 . 8 4 5 5}$ \\
\hline 4. & $\mathrm{CoSO}_{4} \cdot 7 \mathrm{H}_{2} \mathrm{O}$ & $\mathrm{Ni}^{2+}, \mathrm{Mn}^{2+}, \mathrm{Fe}^{2+}, \mathrm{Mg}^{2+}, \mathrm{Cd}^{2+}, \mathrm{Zn}^{2+}$ & $\mathbf{0 . 9 1 7 2}$ \\
\hline 5. & $\mathrm{MnSO}_{4} \cdot 5 \mathrm{H}_{2} \mathrm{O}$ & $\mathrm{Zn}^{2+}, \mathrm{Cu}^{2+}, \mathrm{Mg}^{2+}$ & $\mathbf{0 . 9 9 7 1}$ \\
\hline 6. & $\mathrm{FeSO}_{4} \cdot 7 \mathrm{H}_{2} \mathrm{O}$ & $\mathrm{Ni}^{2+}, \mathrm{Zn}^{2+}, \mathrm{Cu}^{2+}, \mathrm{Mg}^{2+}, \mathrm{Cd}^{2+}, \mathrm{Co}^{2+}$ & $\mathbf{0 . 7 9 8 3}$ \\
\hline 8. & $\left.\mathrm{Ni}^{2+} \mathrm{NO}_{3}\right)_{2} \cdot 6 \mathrm{H}_{2} \mathrm{O}$ & $\mathrm{Mn}^{2+}, \mathrm{Zn}^{2+}, \mathrm{Mg}^{2+}, \mathrm{Co}^{2+}$ & 0.7022 \\
\hline 9. & $\left.\mathrm{Ni}^{2+} \mathrm{NO}_{3}\right)_{2} \cdot 6 \mathrm{H}_{2} \mathrm{O}$ & $\mathrm{Mn}^{2+}, \mathrm{Mg}^{2+}, \mathrm{Co}^{2+}$ & $\mathbf{0 . 9 9 7 0}$ \\
\hline 10. & $\mathrm{NiCl}_{2} \cdot 6 \mathrm{H}_{2} \mathrm{O}$ & $\mathrm{Zn}^{2+}, \mathrm{Mn}^{2+}, \mathrm{Fe}^{2+}, \mathrm{Cu}^{2+}, \mathrm{Co}^{2+}$ & $\mathbf{0 . 9 9 7 4}$ \\
\hline 11. & $\mathrm{~K}_{2} \mathrm{SO}_{4}$ & $\mathrm{Cs}^{+}, \mathrm{Tl}^{+}, \mathrm{Rb}^{+}$ & 0.1041 \\
\hline
\end{tabular}

Table 5. Correlation $\left(\rho_{x y}\right)$ of co-crystallization coefficients $\mathrm{D}_{2 / 1}$ and solubility in the solid phase ( $\left.{ }^{\mathrm{s}} \mathrm{MAX}\right)($ Smolik, 2004)

\subsubsection{The volume of one formal molecule}

The volume of one formal molecule can be calculated, knowing the molar mass of crystallizing salt (compound) and its density, by the following formula $\eta^{3}=10^{24} \frac{M_{x}}{d \cdot N}\left[\AA^{3}\right]$ where: $\mathrm{M}_{\mathrm{x}}-$ molar mass [g/mole], $\mathrm{d}$ - density $\left[\mathrm{g} / \mathrm{cm}^{3}\right], \mathrm{N}$ - Avogadro number $\left.=6,022 \cdot 10^{23} / \mathrm{mole}\right)$. This is very close to that calculated using unit cell parameters $(a, b, c, \alpha, \beta, \gamma)$.

\begin{tabular}{|c|c|c|c|c|c|}
\hline \multirow{3}{*}{$\begin{array}{l}\text { Macro- } \\
\text { com- } \\
\text { ponent }\end{array}$} & \multirow{3}{*}{$\begin{array}{c}\text { Micro- } \\
\text { components }\end{array}$} & \multirow{3}{*}{$\mathrm{y}$} & & & \multirow{3}{*}{ Ref. } \\
\hline & & & $\left|\frac{\Delta \eta^{3}}{\eta^{3}}\right|$ & $\left(\frac{\Delta \eta}{\eta}\right)^{2}$ & \\
\hline & & & \multicolumn{2}{|c|}{$\rho_{x y}$} & \\
\hline \multirow{2}{*}{ (1) } & $\begin{array}{c}\mathrm{Ni}^{2+}, \mathrm{Cu}^{2+}, \mathrm{Co}^{2+}, \mathrm{Zn}^{2+}, \\
\mathrm{Mn}^{2+}, \mathrm{Cd}^{2+}, \mathrm{Ca}^{2+} \mathrm{Sr}^{2+}\end{array}$ & $\ln \mathrm{D}_{2 / 1}$ & -0.8657 & & \multirow{2}{*}{$\begin{array}{c}\text { (Smolik, } \\
\text { 2008) }\end{array}$} \\
\hline & $\mathrm{Ni}^{2+}, \mathrm{Co}^{2+}, \mathrm{Mn}^{2+}$ & $\begin{array}{c}\pi=\ln \mathrm{D}_{2 / 1}- \\
\ln \left(\mathrm{m}_{01} / \mathrm{m}_{02}\right)^{3}\end{array}$ & & -0.9973 & \\
\hline (2) & $\mathrm{Mg}^{2+}, \mathrm{Co}^{2+}, \mathrm{Ni}^{2+}$ & $\begin{array}{c}\pi=\ln \mathrm{D}_{2 / 1}-\ln \\
\left(\mathrm{m}_{01} / \mathrm{m}_{02}\right)^{3}\end{array}$ & & -0.9987 & $\begin{array}{c}\text { (Smolik, } \\
\text { 2011) }\end{array}$ \\
\hline
\end{tabular}

Table 6. The dependence of $\ln \mathrm{D}_{2 / 1}\left(\pi=\ln \mathrm{D}_{2 / 1}-\ln \left(\mathrm{m}_{01} / \mathrm{m}_{02}\right)^{3}\right)$ on various functions of $\eta$ during the crystallization of $\mathrm{Mg}\left(\mathrm{CH}_{3} \mathrm{COO}\right)_{2} \cdot 4 \mathrm{H}_{2} \mathrm{O}(1)$ and $\mathrm{Mn}\left(\mathrm{CH}_{3} \mathrm{COO}\right)_{2} \cdot 4 \mathrm{H}_{2} \mathrm{O}(2)$ at $25^{\circ} \mathrm{C}$ 
According to Urusov (1977) this parameter is better than ionic radius in the evaluation of the effect of geometric factor on $\mathrm{D}_{2 / 1}$ coefficients, because it takes into account real interatomic distances defined by crystal system and unit cell parameters. However, $\eta$ is unambiguous only in ionic crystals of high (cubic) symmetry and in the case of complicated heterodesmic structures of low symmetry these distances become equivocal.

The significant effect of this factor has occurred in some acetate crystallization systems (Table 5).

\subsection{Chemical, physicochemical and crystal-chemical properties of co-crystallizing ions}

\subsubsection{Charge of cation}

The cation charge is one of the most important factors influencing $\mathrm{D}_{2 / 1}$ coefficients. Taking into account the earlier mentioned Latin rule "Similia similibus solvuntur" it might be expected that microcomponent ions having the same charge as that of macrocomponent ion should co-crystallize in higher degree than those of different ion charge. In many crystallization systems this rule is fulfilled, e.g., in the case of crystallization of $\mathrm{FeSO}_{4} \cdot 7 \mathrm{H}_{2} \mathrm{O}$ at $20{ }^{\circ} \mathrm{C}$ the mean $\mathrm{D}_{2 / 1}$ of $\mathrm{M}^{2+}$ ions (of the same charge as the macrocomponent $\mathrm{Fe}^{2+}$ ) are $\sim 14$ (50) times greater than those of $\mathrm{M}^{+}\left(\mathrm{M}^{3+}\right)$ ions (of the charge different from that of macrocomponent) (Fig. 11a), and in the case of $\mathrm{Fe}\left(\mathrm{NH}_{4}\right)\left(\mathrm{SO}_{4}\right)_{2} \cdot 12 \mathrm{H}_{2} \mathrm{O}$ crystallization at $20^{\circ} \mathrm{C}$ the mean $\mathrm{D}_{2 / 1}$ of $\mathrm{M}^{2+}$ ions (of different charge from macrocomponent ions $\mathrm{NH}_{4}{ }^{+}$and $\mathrm{Fe}^{3+}$ ) is $\sim 400$ - 1000 times lower than those of $\mathrm{M}^{+}$and $\mathrm{M}^{3+}$ ions (Fig 11b).

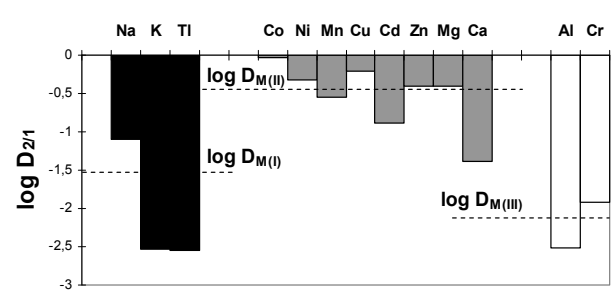

(a)

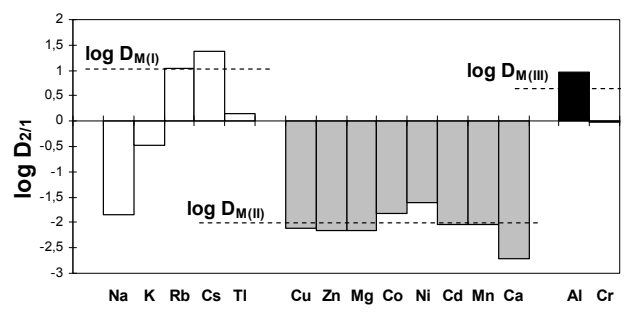

(b)

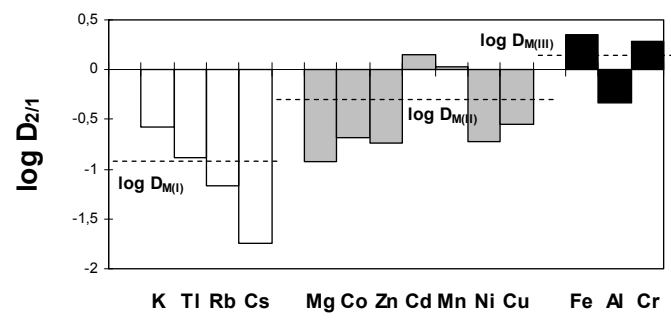

(c)

Fig. 11. The effect of ion charge on $\mathrm{D}_{2 / 1}$ during crystallization of: a) $\mathrm{FeSO}_{4} \cdot 7 \mathrm{H}_{2} \mathrm{O}$ at $20{ }^{\circ} \mathrm{C}$ (Smolik \& Lipowska, 1995); b) Fe( $\mathrm{NH}_{4}$ ) alum at $20{ }^{\circ} \mathrm{C}$; (Smolik, 1995a); c) $\mathrm{Na}_{2} \mathrm{SO}_{4}$ at 50 ०C; (Smolik, 1998b); $\log \mathrm{D}_{\mathrm{M}(\mathrm{I})(\mathrm{M}(\mathrm{II}), \mathrm{M}(\mathrm{III}))}$ - logarithms of mean $\mathrm{D}_{2 / 1}$ for $\mathrm{M}^{+}\left(\mathrm{M}^{2+}, \mathrm{M}^{3+}\right)$ ions 
However, there are crystallization systems where this simple and evident rule is not fulfilled, e.g., during the crystallization of $\mathrm{Na}_{2} \mathrm{SO}_{4}$ at $50{ }^{\circ} \mathrm{C}$ (Fig. 11c). In this case the mean $\mathrm{D}_{2 / 1}$ of $\mathrm{M}^{+}$ions (of the same charge as the macrocomponent $\mathrm{Na}^{+}$) is the lowest. This is caused by the formation of double, less soluble salts by $\mathrm{Na}_{2} \mathrm{SO}_{4}$ with $\mathrm{M}$ (II) and $\mathrm{M}$ (III) sulfates which, because of their structures, are capable of in-build into $\mathrm{Na}_{2} \mathrm{SO}_{4}$ crystal.

\subsubsection{Geometrical factor (ionic radius $(r)$ )}

The geometrical factor, determined by the difference in size of mutually substituting ions, has been considered for a long time as one of the most significant factors affecting the existence of isomorphism. Beginning from the empirical Goldschmidt rule postulating the border of $15 \%$ relative difference of ionic radii for the occurrence of isomorphic substitution, various values of this border (e.g., $5 \%$ ) have been given by other authors. In addition it has occurred that they are dependent on other factors. This parameter was not recommended by Urusov (1977), who preferred to take into consideration the differences in interionic distances in the solid phase. In this way he calculated $\mathrm{D}_{2 / 1}$ values for $\mathrm{M}^{+}$ions were strictly consistent with those experimental ones during the crystallization of alkali metal halides from melt (Urusov \& Kravchuk, 1976). However, as proved by the same author, correlation of interionc distances in the solid phase and $\mathrm{D}_{2 / 1}$ values obtained during the crystallization from aqueous solutions occurred as significantly weaker (Urusov, 1980). Moreover, the results of many investigations [(Smolik, 1993, 1995, 1998a, 2003,2007, 2010) indicate that ionic radius can be a useful parameter in the evaluation of co-crystallization coefficients. Some typical dependences of $\mathrm{D}_{2 / 1}$ coefficients on ionic radii have been presented in Fig. 12 $a, b, c, d$.

We can observe some types of the dependence of $\mathrm{D}_{2 / 1}$ coefficients on ionic radius: a) monotonic, hyperbolic drop of $\mathrm{D}_{2 / 1}$ with the increase of ionic radius (if the case of $\mathrm{Cu}^{2+}$ is ignored, because of the structure of triclinic $\mathrm{CuSO}_{4} 5 \mathrm{H}_{2} \mathrm{O}$ significantly departing from the structures of other sulfates); b) the existence of the maximum of $\mathrm{D}_{2 / 1}$ coefficients for ions, whose radii are closest to the radius of macrocomponent and the monotonic drop of $\mathrm{D}_{2 / 1}$ as the absolute value of the difference in ionic radii of macrocomponent and microcomponent increases; c) similar type like " $b$ ", disturbed in the case of (mainly) $\mathrm{Cu}^{2+}$ because of the almost identical structure of triclinic $\mathrm{CuSO}_{4} \cdot 5 \mathrm{H}_{2} \mathrm{O}$ and $\mathrm{MnSO}_{4} \cdot 5 \mathrm{H}_{2} \mathrm{O}$; d) there are two ranges of higher $\mathrm{D}_{2 / 1}$ coefficients corresponding to the values of ionic radii very close to those of two macrocomponent ions $\mathrm{NH}_{4}{ }^{+}$and $\mathrm{Fe}^{3+}$.

Very high correlation coefficients of $\ln \mathrm{D}_{2 / 1}$ and $\left|\Delta \mathrm{r} / \mathrm{r}_{\mathrm{M}}\right|$ or $\left(\Delta \mathrm{r} / \mathrm{r}_{\mathrm{M}}\right)^{2}$ in some crystallization systems (Table 7 ) indicate that these co-crystallization coefficients strongly depend on the similarity of ionic radii of micro and macrocomponents.

Coefficients of $\mathrm{Ca}^{2+}$ co-crystallization with various sulfate hydrates $\mathrm{MSO}_{4} \mathrm{nH}_{2} \mathrm{O}$, taking into account slight solubility of $\mathrm{CaSO}_{4} \cdot 2 \mathrm{H}_{2} \mathrm{O}$, should be very high. However, because of its large radius $\mathrm{r}_{\mathrm{Ca} 2+}, \mathrm{Ca}^{2+}$ ion cannot in-build into $\mathrm{MSO}_{4} \cdot \mathrm{nH}_{2} \mathrm{O}$ crystals of smaller $\mathrm{M}^{2+}$ ions. Therefore, the ionic radius of the macrocomponent is a more important factor than the

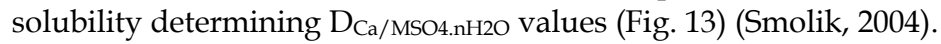

Thus, ionic radii in the case of crystallization of salts from aqueous solutions can be a convenient and important parameter for the investigation and sometimes evaluation of $D_{2 / 1}$ 


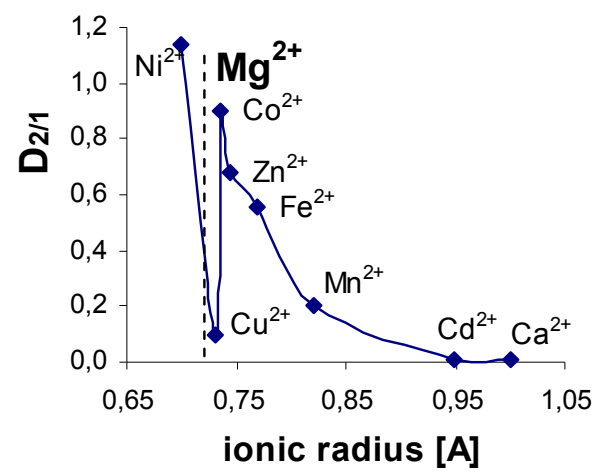

(a)

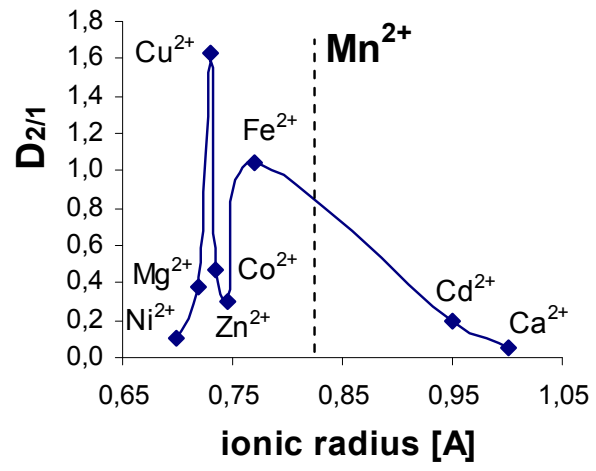

(c)

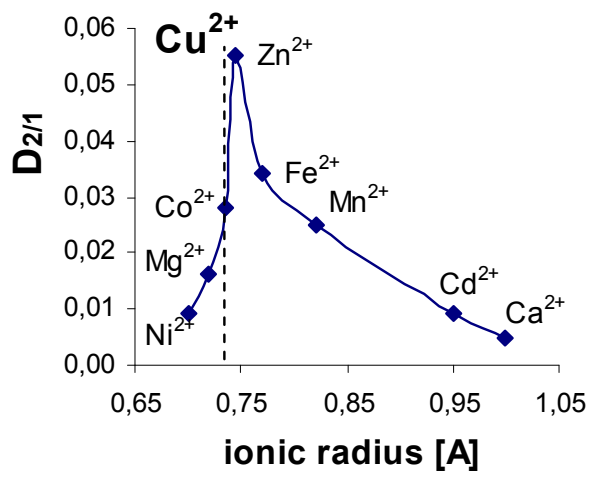

(b)

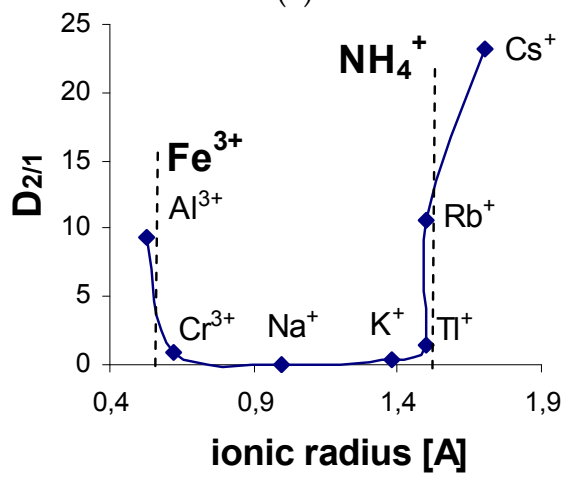

(d)

Fig. 12. The effect of ionic radius on coefficients $\mathrm{D}_{2 / 1}$ during the crystallization of : a $\mathrm{MgSO}_{4} \cdot 7 \mathrm{H}_{2} \mathrm{O}$ at $25^{\circ} \mathrm{C}$ (Smolik, 1999a), b - $\mathrm{CuSO}_{4} \cdot 5 \mathrm{H}_{2} \mathrm{O}$ at $25^{\circ} \mathrm{C}$ (Smolik \& Zolotajkin, 1993), c $-\mathrm{MnSO}_{4} \cdot 5 \mathrm{H}_{2} \mathrm{O}$ at $20{ }^{\circ} \mathrm{C}$ (Smolik et al., 1995), d $-\mathrm{NH}_{4} \mathrm{Fe}$ alum at $20 \circ \mathrm{C}$ (Smolik, 1995c)

\begin{tabular}{|c|c|c|c|}
\hline \multirow{2}{*}{$\begin{array}{c}\text { Macro- } \\
\text { component }\end{array}$} & \multirow{2}{*}{$\begin{array}{l}\text { Microcomponents } \\
\qquad\left(\mathrm{M}^{2+}\right)\end{array}$} & \multicolumn{2}{|c|}{$\begin{array}{l}\text { Correlation coefficients } \rho_{x y} \\
\text { of } \ln D_{2 / 1} \text { and: }\end{array}$} \\
\hline & & $\left|\Delta \mathrm{r} / \mathrm{r}_{\mathrm{M}}\right|$ & $\left(\Delta \mathrm{r} / \mathrm{r}_{\mathrm{M}}\right)^{2}$ \\
\hline \multirow{2}{*}{$\begin{array}{l}\text { Orthorhombic } \\
\mathrm{MgSO}_{4} \cdot 7 \mathrm{H}_{2} \mathrm{O}\end{array}$} & $\mathrm{Ni}^{2+}, \mathrm{Cu}^{2+}, \mathrm{Co}^{2+}, \mathrm{Zn}^{2+}, \mathrm{Fe}^{2+}, \mathrm{Mn}^{2+}, \mathrm{Cd}^{2+}, \mathrm{Ca}^{2+}$ & $-0.9061^{*}$ & \\
\hline & $\mathrm{Co}^{2+}, \mathrm{Fe}^{2+}, \mathrm{Mn}^{2+}, \mathrm{Cd}^{2+}, \mathrm{Ca}^{2+}$ (monoclinic) & -0.9992 & \\
\hline \multirow{2}{*}{$\begin{array}{c}\text { triclinic } \\
\mathrm{MnSO}_{4} \cdot 5 \mathrm{H}_{2} \mathrm{O}\end{array}$} & $\mathrm{Ni}^{2+}, \mathrm{Cu}^{2+}, \mathrm{Co}^{2+}, \mathrm{Zn}^{2+}, \mathrm{Fe}^{2+}, \mathrm{Mn}^{2+}, \mathrm{Cd}^{2+}, \mathrm{Ca}^{2+}$ & & -0.8353 \\
\hline & $\mathrm{Co}^{2+}, \mathrm{Fe}^{2+}, \mathrm{Cd}^{2+}, \mathrm{Ca}^{2+}$ (monoclinic) & & -0.9948 \\
\hline \multirow{2}{*}{$\begin{array}{c}\text { triclinic } \\
\mathrm{CuSO}_{4} \cdot 5 \mathrm{H}_{2} \mathrm{O}\end{array}$} & $\mathrm{Ni}^{2+}, \mathrm{Cu}^{2+}, \mathrm{Co}^{2+}, \mathrm{Zn}^{2+}, \mathrm{Fe}^{2+}, \mathrm{Mn}^{2+}, \mathrm{Cd}^{2+}, \mathrm{Ca}^{2+}$ & & -0.6659 \\
\hline & $\mathrm{Co}^{2+}, \mathrm{Fe}^{2+}, \mathrm{Mn}^{2+}, \mathrm{Cd}^{2+}, \mathrm{Ca}^{2+}$ (monoclinic) & & -0.9949 \\
\hline
\end{tabular}

* -significant $\rho_{\mathrm{xy}}$ (for the confidence level of 0.95) are marked bold (Smolik, 2004)

Table 7. Correlation coefficients ( $\left.\rho_{x y}\right)$ of $\ln D_{2 / 1}$ and $\left(\Delta r / r_{M}\right)^{2}$ (or $\left.\left|\Delta r / r_{M}\right|\right)$ in some sulfate crystallization systems for all ions or those ions whose sulfate hydrates are monoclinic 
coefficients. The comparison of correlation coefficient $\left(\rho_{x y}\right)$ of $\pi=\left[\ln \mathrm{D}_{2 / 1}-\ln \left(\mathrm{m}_{01} / \mathrm{m}_{02}\right)^{3}\right][\mathrm{y}]$ and $\left|\left(\left(\mathrm{r}_{\mathrm{Co} 2+}\right)^{3}-\left(\mathrm{r}_{\mathrm{M} 2+}\right)^{3}\right) /\left(\mathrm{r}_{\mathrm{Co} 2+}\right)^{3}\right|[\mathrm{x}]\left(\rho_{x y}=-0.9174\right)$ with analogous correlation coefficient of $\pi[\mathrm{y}]$ and $\left|\left(\left(\eta_{\mathrm{Co} 2+}\right)^{3}-\left(\eta_{\mathrm{M} 2+}\right)^{3}\right) /\left(\eta_{\mathrm{Co} 2+}\right)^{3}\right|[\mathrm{x}]\left(\rho_{x y}=-0.8590\right)$ indicates that the latter parameter, preferred by Urusov (1977) to estimate $\mathrm{D}_{2 / 1}$ values, is in the case of $\mathrm{Co}\left(\mathrm{CH}_{3} \mathrm{COO}\right)_{2} \cdot 4 \mathrm{H}_{2} \mathrm{O}$ crystallization not better than the first one related to ionic radius (Smolik et al., 2007).

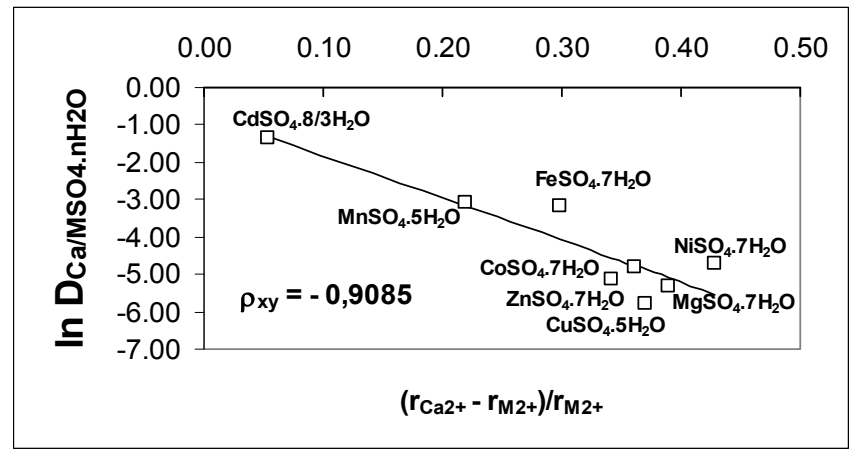

Fig. 13. The dependence of $\ln \mathrm{D}_{\mathrm{Ca} / \mathrm{MSO} 4 . \mathrm{nH} 2 \mathrm{O}}$ on ionic radii of macrocomponent ions $\left(\mathrm{M}^{2+}\right)$ (Smolik, 2004)

\subsubsection{Electronegativity of mutually substituting elements $\Phi(\varepsilon)$}

Apart from the geometric factor, the partition coefficients may be affected by the nature (polarity) of the chemical bond of mutually substituting components. The exact quantitative characteristic of the polarity of the chemical bond is given by the integral of overlapping of atomic orbitals, but such data for many isomorphous systems are not available yet. So some authors (Urusov, 1977; Ringwood, 1955) consider the difference in electronegativity of elements as a measure of polarity.

Spectacular examples of a huge effect of this factor on $\mathrm{D}_{2 / 1}$ are given by (Urusov, 1977) where during the crystallization from the melt in systems $\mathrm{NaBr}-\mathrm{AgBr}, \mathrm{NaCl}-\mathrm{AgCl}$, and $\mathrm{NaCl}-\mathrm{CuCl}$, co-crystallization does not take place, although the relative differences of interionic distances of co-crystallizing isomorphous salts are very low or close to zero. The difference in the effective ionic charges of $\mathrm{Ag}(\mathrm{Cu})$ and $\mathrm{Na}$ in these systems was believed to be responsible for the extremely low miscibility of these systems (Kirkova et al., 1996).

In the case of crystallization of several groups of salts from aqueous solutions, the effect of electronegativity of mutually substituting components on distribution coefficients has been compared with the effect of ionic radius. However, for this comparison function $\pi=\ln \mathrm{D}_{2 / 1}-\ln \left(\mathrm{m}_{01} / \mathrm{m}_{02}\right)^{\mathrm{v} / \mathrm{b}}$ has been taken into consideration (it allows for the solubility ratio of co-crystallizing salts). The results are given in Table 8 .

As it can be seen, higher correlation coefficients $\left|\rho_{\mathrm{xy}}\right|$ of $\pi$ and $\Phi(\varepsilon)$ than those of $\pi$ and $f(\mathrm{r})$ occur in the case of chlorides $\left(\mathrm{MCl}_{2} \cdot \mathrm{nH}_{2} \mathrm{O}\right)$ and formates $\left(\mathrm{M}(\mathrm{HCOO})_{2} \cdot 2 \mathrm{H}_{2} \mathrm{O}\right)$. Generally, more significant correlation coefficients $\left|\rho_{x y}\right|$ occur in the case when in coordination surroundings of appropriate cations $\mathrm{M}^{\mathrm{n}+}$ in the solid phase, halogen or formate ions appear 
as well, apart from oxide ligands originating from water or inorganic anions. However, a kind of dependence of $\mathrm{D}_{2 / 1}$ coefficients on electronegativity has not been univocally defined and the kind of function $\Phi(\varepsilon)$ is very important to decide if unilateral isomorphism occurs, in spite of a buffering action of surrounding hydrate mantle (Kirkova et al., 1996).

\begin{tabular}{|c|c|c|}
\hline \multirow[t]{2}{*}{ Groups of considered salts } & \multicolumn{2}{|c|}{$\begin{array}{l}\text { maximal values of correlation coefficients }\left|\rho_{x y}\right| \text { of } \\
\text { function } \pi=\ln D_{2 / 1}-\ln \left(\mathrm{m}_{01} / \mathrm{m}_{02}\right)^{v / b}\end{array}$} \\
\hline & and $f(\mathrm{r})$ & and $\Phi(\varepsilon)$ \\
\hline $\mathrm{MSO}_{4} \cdot \mathrm{nH}_{2} \mathrm{O}$ & 0.7309 & 0.6377 \\
\hline $\mathrm{M}\left(\mathrm{NO}_{3}\right)_{2} \cdot \mathrm{nH}_{2} \mathrm{O}$ & 0.9421 & 0.6502 \\
\hline $\mathrm{MCl}_{2} \cdot \mathrm{nH}_{2} \mathrm{O}$ & 0.6258 & 0.7328 \\
\hline $\mathrm{M}^{\mathrm{I} M} \mathrm{MII}^{\mathrm{II}}\left(\mathrm{SO}_{4}\right)_{2} \cdot 12 \mathrm{H}_{2} \mathrm{O}, \mathrm{M}(\mathrm{I})$ & 0.9188 & non-significant \\
\hline $\mathrm{M}^{\mathrm{I} M} \mathrm{M}^{\mathrm{III}}\left(\mathrm{SO}_{4}\right)_{2} \cdot 12 \mathrm{H}_{2} \mathrm{O}, \mathrm{M}(\mathrm{III})$ & 0.7651 & non-significant \\
\hline $\mathrm{M}^{\mathrm{I}} \mathrm{M}^{\mathrm{II}}\left(\mathrm{SO}_{4}\right)_{2} \cdot 6 \mathrm{H}_{2} \mathrm{O}, \mathrm{M}(\mathrm{II})$ & 0.4921 & 0.3358 \\
\hline $\mathrm{M}(\mathrm{HCOO})_{2} \cdot 2 \mathrm{H}_{2} \mathrm{O}$ & non-significant & 0.7604 \\
\hline $\mathrm{M}_{2} \mathrm{SO}_{4} \cdot \mathrm{nH}_{2} \mathrm{O}$ & 0.8005 & 0.6900 \\
\hline MX & 0.8749 & 0.8745 \\
\hline
\end{tabular}

Table 8. Comparison of absolute maximal values of correlation coefficients of functions $\pi=\ln D_{2 / 1}-\ln \left(\mathrm{m}_{01} / \mathrm{m}_{02}\right)^{v / b}$ and $f(\mathrm{r})$ or $\Phi(\varepsilon)$ in considered groups of salts (Smolik, 2004)

To evaluate if unilateral isomorphism occurs during low temperature crystallization from aqueous solutions (according to the rule known for a long time in geology [Urusov, 1970] that lithophilic elements are substituted in the solid phase by chalcophilic and siderophilic elements and not to the contrary) several criteria may be applied (Smolik, 2004). The strongest of them in the case of co-crystallization of more $\left(\mathrm{M}_{1}\right)$ and less $\left(\mathrm{M}_{2}\right)$ electronegative ions $\left(\varepsilon_{1}>\varepsilon_{2}\right)$ looks as follows: $\Theta>3$, where $\Theta=\theta_{1 / 2} / \theta_{2 / 1} ; \theta_{1 / 2}=\left(\mathrm{D}_{1 / 2}\right)_{\text {exp. }} /\left(\mathrm{D}_{1 / 2}\right)_{\mathrm{cal}}$ and $\theta_{2 / 1}=\left(\mathrm{D}_{2 / 1}\right)_{\text {exp. }} /\left(\mathrm{D}_{2 / 1}\right)_{\mathrm{cal}}$; $\left(\mathrm{D}_{1 / 2}\right)_{\mathrm{cal}}=\left(\mathrm{m}_{02} / \mathrm{m}_{01}\right)^{v / \mathrm{b}} ;\left(\mathrm{D}_{2 / 1}\right)_{\mathrm{cal}}=\left(\mathrm{m}_{01} / \mathrm{m}_{02}\right)^{\mathrm{v} / \mathrm{b}}$

So:

$$
\ln \Theta=\ln \theta_{1 / 2}-\ln \theta_{2 / 1}=\left[\ln \left(\mathrm{D}_{1 / 2}\right)_{\exp }-\ln \left(\mathrm{m}_{02} / \mathrm{m}_{01}\right)^{\mathrm{v} / \mathrm{b}}\right]-\left[\ln \left(\mathrm{D}_{2 / 1}\right)_{\exp }-\ln \left(\mathrm{m}_{01} / \mathrm{m}_{02}\right)^{\mathrm{v} / \mathrm{b}}\right]>1.1 .
$$

The value $\theta_{1 / 2}\left(\theta_{2 / 1}\right)$ is a measure of the extension (or diminution) of the experimental $\left(\mathrm{D}_{1 / 2}\right)_{\exp }\left(\left(\mathrm{D}_{2 / 1}\right)_{\exp }\right)$ in relation to $\left(\mathrm{D}_{1 / 2}\right)_{\mathrm{cal}}\left(\left(\mathrm{D}_{2 / 1}\right)_{\mathrm{cal}}\right)$, which may be brought about by the effect of electronegativity. $\theta_{1 / 2}$ and $\theta_{2 / 1}$ coefficients allowing for the solubility of corresponding salts are independent of the structure and the relative difference in interionic distances of cocrystallizing isomorphous salts. Therefore, they are most adequate to evaluate the occurrence of unilateral isomorphism. The results of such an analysis of all isomorphous salts forming hydrates, for which $\mathrm{D}_{2 / 1}\left(\mathrm{D}_{1 / 2}\right)$ coefficients have been available, show the lack of any example of unilateral isomorphism (Smolik, 2004)

\subsubsection{Electronic configuration}

Electronic configuration of $\mathrm{M}^{\mathrm{n}+}$ ions, as well as crystal field stabilization energy in high spin octahedral complexes $\left[\mathrm{ML}_{6}\right]$, may influence the crystal structure of co-crystallizing salts. According to their electronic configuration these ions may be divided into two groups: 
closed shell ions having the configuration $\mathrm{p}^{6}\left(\mathrm{Mg}^{2+}, \mathrm{Ca}^{2+}, \mathrm{Sr}^{2+}, \mathrm{Ba}^{2+}\right)$ or $\mathrm{d}^{10}\left(\mathrm{Zn}^{2+}, \mathrm{Cd}^{2+}\right)$, as well as $\mathrm{d}^{5}$, but only when they are in the high spin state $\left(\mathrm{Mn}^{2+}\right)$. The crystal field stabilization energy (CFSE) of such ions is zero;

open shell ions having the configuration $\mathrm{d}^{\mathrm{n}}(\mathrm{n} \neq 0,5,10)$, where CFSE $\neq 0$.

In the first case the energy of these ionic coordination compounds due to the metal ions would be independent of the spatial orientation of the metal-ligand bonds. For this reason these metal ions permit variations over wide ranges of structural parameters, mainly the structure defining angles (angular deformations) (Balarew, 1987).

In the second case the CFSE depends on the orientation of metal-ligand bonds. Therefore, there are some preferred structures, for which CFSE has a maximum value, and the change in geometry of coordination polyhedron with respect to these preferred structures is related to CFSE losses (Balarew, 1987). However, the amount of the CFSE is only $5-10 \%$ of the whole bonding energy in the crystals and other factors mentioned previously (ionic radii, their charge, energy of metal - ligand bonds) determine the structure of predominantly ionic crystals (Balarew, 1987). Hence its effect on $\mathrm{D}_{2 / 1}$ coefficients is rarely observable.

Some examples of the direct influence of electron configuration of ion on $\mathrm{D}_{2 / 1}$ coefficients are presented in Tables 9-10.

\begin{tabular}{|c|c|c|}
\hline Ion $\mathrm{M}^{2+}$ & Electron configuration & $\mathrm{D}_{2 / 1}$ \\
\hline $\mathrm{Mg}^{2+}$ & $1 s^{2} 2 s^{2} p^{6}$ & $0.009 \pm 0.005$ \\
\hline $\mathrm{Ca}^{2+}$ & $1 s^{2} 2 s^{2} p^{6} 3 s^{2} p^{6}$ & $0.022 \pm 0.008$ \\
\hline $\mathrm{Sr}^{2+}$ & $1 s^{2} 2 s^{2} p^{6} 3 s^{2} p^{6} 4 s^{2} p^{6}$ & $0.013 \pm 0.006$ \\
\hline $\mathrm{Zn}^{2+}$ & $1 s^{2} 2 s^{2} p^{6} 3 s^{2} p^{6} d^{10}$ & $0.014 \pm 0.005$ \\
\hline $\mathrm{Cd}^{2+}$ & $1 s^{2} 2 s^{2} p^{6} 3 s^{2} p^{6} d^{10} 4 s^{2} p^{6} d^{10}$ & $0.010 \pm 0.006$ \\
\hline $\mathrm{Cu}^{2+}$ & $1 s^{2} 2 s^{2} p^{6} 3 s^{2} p^{6} d^{9}$ & $0.040 \pm 0.007$ \\
\hline $\mathrm{Mn}^{2+}$ & $1 s^{2} 2 s^{2} p^{6} 3 s^{2} p^{6} d^{5}$ & $0.40 \pm 0.02$ \\
\hline $\mathrm{Fe}^{2+}$ & $1 s^{2} 2 s^{2} p^{6} 3 s^{2} p^{6} d^{6}$ & $1.70 \pm 0.20$ \\
\hline $\mathrm{Co}^{2+}$ & $1 s^{2} 2 s^{2} p^{6} 3 s^{2} p^{6} d^{7}$ & $2.60 \pm 0.30$ \\
\hline
\end{tabular}

Table 9. The effect the electron configuration on $\mathrm{D}_{2 / 1}$ coefficients during the crystallization of $\mathrm{NiCl}_{2} \cdot 6 \mathrm{H}_{2} \mathrm{O}$ at $20{ }^{\circ} \mathrm{C}$ (Smolik, 1999b)

As it can be seen, the direct effect of electronic configuration of microcomponent ions on coefficients $\mathrm{D}_{2 / 1}$ is most distinct in the case of chloride, formate and acetate crystallization

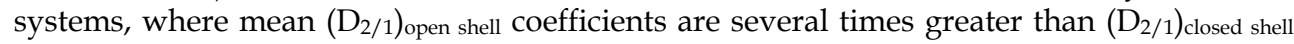
ones. This effect is lower in sulfate and nitrate crystallization systems.

The direct effect of the electron configuration of ions depends on the kind of anion of the crystallizing salt. It is slightly perceptible in the case of nitates and sulfates, where, besides water molecules, oxoanions $\mathrm{NO}_{3}{ }^{-}$and $\mathrm{SO}_{4}{ }^{2-}$ appear. The valence available between oxygen and metal ion, which is a measure of their anion base strength equals: 0,33 and 0,50 , respectively, and is very close to that of water molecules $(0,40)$ (Balarew, 1987). Because of a great excess of water both in the liquid phase and in the solid one (particularly in hepta and hexahydrates), these anions cannot compete with water molecules in the bonding of metal ion. So the environment around both metal cations will be formed mainly by water molecules. 


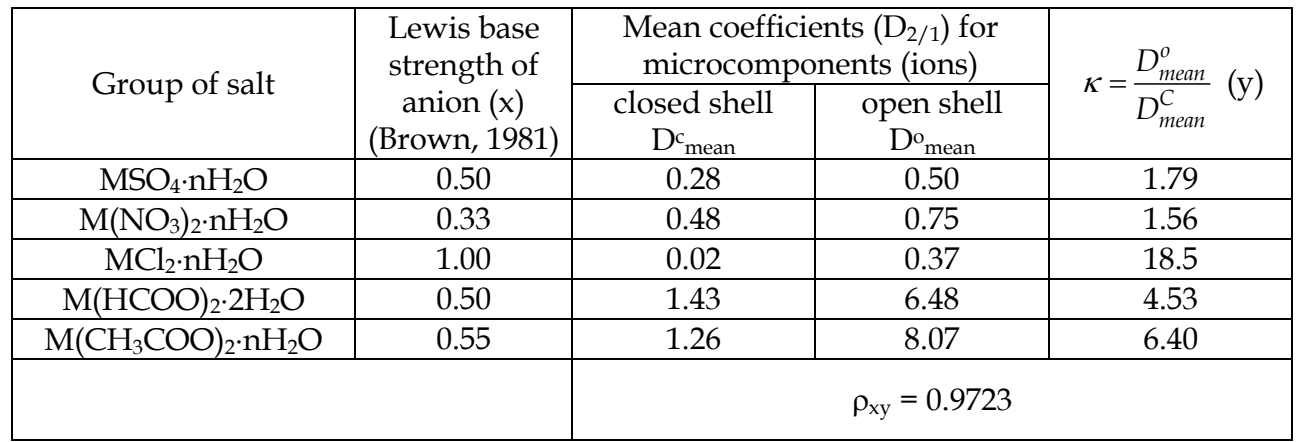

Table 10. The effect of electron configuration of microcomponents (ions) on their $\mathrm{D}_{2 / 1}$ coefficients in considered groups of simple salts (Smolik, 2004)

The base strength of anions occurring in chloride, acetate and formate systems is generally higher than that for water molecules and equals: 1,00 for $\mathrm{Cl}^{-}, 0,55$ for $\mathrm{CH}_{3} \mathrm{COO}^{-}$and 0,50 for $\mathrm{HCOO}^{-}$(Balarew, 1987)]. Due to this, as well as because of lower excess of water in relation to $\mathrm{CH}_{3} \mathrm{COO}^{-}$and $\mathrm{HCOO}^{-}$in the solid phase, these anions can compete with water molecules in coordination surrounding cations of macro and microcomponents. The presence of both kinds of ligands (water molecule and anions $\mathrm{Cl}^{-}, \mathrm{CH}_{3} \mathrm{COO}^{-}$or $\mathrm{HCOO}^{-}$) differing in size and charge) causes stronger deformation of the octahedral surrounding of these cations as compared with the presence of one ligand. This deformation depends on the electron configuration of the cation of both the macrocomponent and microcomponent. Therefore, this factor may influence the ability of mutual substitution of those octahedra (deformed to a different degree), whose measure is coefficient $\mathrm{D}_{2 / 1}$.

The dependence of coefficients $\mathrm{D}_{2 / 1}$ on electron configuration is usually connected with their dependence on the crystal field stabilization energy (s), which may be expressed quantitatively for high spin octahedral complexes (most of them occurring in the structures of the considered salts) in $\mathrm{kJ} / \mathrm{mol}$ or in Dq (where Dq - natural theoretical unit for crystalfield splitting energies (Porterfield, 1993). Thus, it is possible to characterize quantitatively this dependence calculating the correlation coefficients of $\ln D_{2 / 1}$ or $\pi=\ln D_{2 / 1}$ $\ln \left(\mathrm{m}_{01} / \mathrm{m}_{02}\right)^{v / b}$ and $\Delta \mathrm{s}=\mathrm{s}_{\mathrm{MACR}}-\mathrm{s}_{\text {micr }}|\Delta \mathrm{s}|$, or $(\Delta \mathrm{s})^{2}$.

\begin{tabular}{|c|c|c|c|c|c|}
\hline \multirow{2}{*}{$\begin{array}{c}\text { Number of } \\
\text { crystallization } \\
\text { systems }\end{array}$} & \multicolumn{5}{|c|}{ correlation coefficients $\left(\rho_{\mathrm{xy}}\right)$ of $\pi=\ln \mathrm{D}_{2 / 1}-\ln \left(\mathrm{m}_{01} / \mathrm{m}_{02}\right)^{3}$ and } \\
\cline { 2 - 6 } & $f(\mathrm{r})$ & $f(\delta)$ & $\Delta \mathrm{n}$ & $\Delta \varepsilon$ & $\Delta \mathrm{s}$ \\
\hline 37 & 0.4156 & -0.1998 & -0.1170 & $\mathbf{0 . 7 6 0 4}$ & $\mathbf{0 . 8 4 8 6}$ \\
\hline
\end{tabular}

Table 11. Comparison of correlation coefficients $\left(\rho_{\mathrm{xy}}\right)$ of $\pi=\ln \mathrm{D}_{2 / 1^{-}} \ln \left(\mathrm{m}_{01} / \mathrm{m}_{02}\right)^{3}$ and functions of some factors affecting co-crystallization coefficients $\mathrm{D}_{2 / 1}$ in formate crystallization systems (Smolik, 2004)

The direct effect of $\Delta s$ on $\ln \mathrm{D}_{2 / 1}$ is very slight in most considered groups of salts, but having taken into account the solubility ratio of the co-crystallizing salts, the found correlation coefficients of $\pi=\ln \mathrm{D}_{2 / 1^{-}} \ln \left(\mathrm{m}_{01} / \mathrm{m}_{02}\right)^{\mathrm{v} / \mathrm{b}}$ and $\Delta \mathrm{s}$ are relatively high only for formate crystallization systems $\left(\rho_{x y}=\mathbf{0 . 8 4 8 6}\right)$. In this group of salts, this correlation coefficient of $\pi$ and $\Delta \mathrm{s}$ is the highest as compared to the ones involving all analysed factors (Table 11). 
Significant correlation coefficients of $\pi=\ln D_{2 / 1}-\ln \left(\mathrm{m}_{01} / \mathrm{m}_{02}\right)^{v / b}$ and $|\Delta \mathrm{s}|$ or $(\Delta \mathrm{s})^{2}$ occur in none of the considered groups of salts, which means that $\pi$ does not depend (in them) on the similarity of the CFSE of the macrocomponent and microcomponent ion.

\subsubsection{Cation hardness (h)}

The concept of cation and anion hardness introduced by Pearson (1963) was utilized by Balarew and co-workers (1984) to solve some crystal-chemical problems. Based on a quantitative definition of hardness (Klopman, 1968) and using his procedure they determined hardness of several open shell cations $\left(\mathrm{Mn}^{2+}, \mathrm{Fe}^{2+}, \mathrm{Co}^{2+}, \mathrm{Ni}^{2+} \mathrm{i} \mathrm{Cu}{ }^{2+}\right)$, which together with the values given by Klopman for anions and other cations they used for the anticipation of a kind of coordination polyhedra in these compounds and their structure. The hardness of several other cations was given by Tepavičarova et al. (1995).

The hardness of cations affecting their coordination surrounding in the case of several ligands of different anion hardness may change the crystal structure of appropriate hydrates causing the formation of pure simple salts, solid solutions or double salts (Balarew, 1987) and therefore, influencing $\mathrm{D}_{2 / 1}$ coefficients.

Absolute values of the determined correlation coefficients $\left(\rho_{x y}\right)$ of $\ln \mathrm{D}_{2 / 1}$ and h are generally low (Smolik, 2004). However, after taking into account the solubility ratio of the cocrystallizing salts (function $\left.\pi=\ln \mathrm{D}_{2 / 1}-\ln \left(\mathrm{m}_{01} / \mathrm{m}_{02}\right)^{v / b}\right), \rho_{x y}$ values are significant for sulfates $\left(\mathrm{MSO}_{4} \mathrm{nH}_{2} \mathrm{O}\right.$ and $\left.\mathrm{M}_{2} \mathrm{SO}_{4} \times \mathrm{H}_{2} \mathrm{O}\right)$, chlorides $\left(\mathrm{MCl}_{2} \mathrm{nH}_{2} \mathrm{O}\right)$ and alkali halides $\mathrm{MX}(\mathrm{X}=$ $\left.\mathrm{Cl}^{-}, \mathrm{Br}^{-}, \mathrm{I}^{-}\right)$, particularly in the presence of $\mathrm{Tl}^{+}$and become the highest $\left(\mid\left(\rho_{\mathrm{xy}}\right)\right.$ śr $\left._{\mathrm{r}}>0.80\right)$ and significant in chloride $\left(\mathrm{MCl}_{2} \cdot \mathrm{nH}_{2} \mathrm{O}\right)$ and halide $(\mathrm{MX})$ crystallization systems. In each case they are negative, which means that with the increasing similarity of macro and microcomponent (with regard to hardness) $\pi$ values grow.

Low values of $\rho_{x y}$ occur in groups of salts, where coordination surrounding of cations is homogeneous. It is composed of water molecules, which are hard ligands and anions $\mathrm{NO}_{3}^{-}$, $\mathrm{SO}_{4}{ }^{2-}$ and $\mathrm{CH}_{3} \mathrm{COO}^{-}$, classified as hard bases. In chloride crystallization systems $\left(\mathrm{MCl}_{2} \cdot \mathrm{nH}_{2} \mathrm{O}\right)$ anions $\mathrm{Cl}^{-}$occur, whose hardness is less than that of water molecules, and in halogen crystallization systems the cation surrounding in the solid phase consists only of chloride, bromide and iodide anions, which are classified as decidedly soft anions. The greatest effect of hardness on co-crystallization coefficients appears here (particularly in the presence of $\mathrm{Tl}^{+}$ions significantly differing in their hardness from alkali ions).

\section{Possibility of estimation of $D_{2 / 1}$ coefficients basing on the determined dependences}

The determined correlation coefficients of $\mathrm{D}_{2 / 1}$ or $\pi=\ln \mathrm{D}_{2 / 1}-\ln \left(\mathrm{m}_{01} / \mathrm{m}_{02}\right)^{\mathrm{v} / \mathrm{b}}$ and various functions of ionic radii (r), electronegativity $(\varepsilon)$, crystal field stabilization energy (s), hardness of cations (h), number of molecules of crystallization water (n), the volume of one formal molecule of hydrate salt $\left(\eta^{3}\right)$ permit to find a kind of functions $(f, \varphi, \psi, \ldots)$ of these parameters and to estimate coefficients $\left(w_{1}, w_{2}, w_{3}, \ldots\right)$ in the general equation (19) for the evaluation of $D_{2 / 1}$ coefficients. Some particular equations of such a general type for the estimation of $\mathrm{D}_{2 / 1}$ in several groups of crystallization systems (macrocomponent microcomponents) at average error not exceeding 31\% are presented in Table $\mathbf{1 2 .}$ 


\begin{tabular}{|c|c|c|c|c|}
\hline $\begin{array}{c}\text { Macro- } \\
\text { component }\end{array}$ & $\begin{array}{l}\text { Micro- } \\
\text { compo- } \\
\text { nents } \\
\left(\mathrm{Mn}^{+}\right)(1)\end{array}$ & $\mathrm{k}$ & Equation & $\begin{array}{l}\Delta_{\mathrm{av}} \\
{[\%]}\end{array}$ \\
\hline \multirow{3}{*}{$\begin{array}{c}\text { orthorhombic } \\
\mathrm{M}^{\prime} \mathrm{SO}_{4} \cdot 7 \mathrm{H}_{2} \mathrm{O} \\
\mathrm{M}^{\prime}=\{\mathrm{Mg}, \mathrm{Zn}, \mathrm{Ni}\}\end{array}$} & $\begin{array}{l}\mathrm{Co}^{2+}, \mathrm{Fe}^{2+} \\
\mathrm{Mn}^{2+}, \mathrm{Cd}^{2+}\end{array}$ & \multirow{3}{*}{21} & $D_{2 / 1}=0.362 \cdot\left(\frac{m_{01}}{m_{02}}\right)^{2} \cdot \exp \left(-25.95 \cdot\left(\frac{r_{1}-r_{2}}{r_{1}}\right)^{2}+0,0072\right)$ & \multirow{3}{*}{21.6} \\
\hline & $\mathrm{Cu}^{2+}$ & & $D_{2 / 1}=0.020 \cdot\left(\frac{m_{01}}{m_{02}}\right)^{2} \cdot \exp \left(-25.95 \cdot\left(\frac{r_{1}-r_{2}}{r_{2}}\right)^{2}+0,0072\right)$ & \\
\hline & $\begin{array}{c}\mathrm{Ni}^{2+} \\
\mathrm{Mg}^{2+}, \mathrm{Zn}^{2+}\end{array}$ & & $D_{2 / 1}=\left(\frac{m_{01}}{m_{02}}\right)^{2} \cdot \exp \left(-25.95 \cdot\left(\frac{r_{1}-r_{2}}{r_{1}}\right)^{2}+0,0072\right)$ & \\
\hline $\begin{array}{c}\text { orthorhombic } \\
\mathrm{M}^{\prime}\left(\mathrm{NO}_{3}\right)_{2} \cdot 6 \mathrm{H}_{2} \mathrm{O} \\
\mathrm{M}^{\prime}=\{\mathrm{Zn}, \mathrm{Mn}\}\end{array}$ & $\mid \begin{array}{c}\mathrm{Ni}^{2+}, \mathrm{Mg}^{2+} \\
\mathrm{Zn}^{2+}, \mathrm{Co}^{2+} \\
\mathrm{Mn}^{2+}\end{array}$ & 8 & $D_{2 / 1}=\left(\frac{m_{01}}{m_{02}}\right)^{3} \cdot \exp \left(-55.83 \cdot\left(\frac{r_{1}-r_{2}}{r_{1}}\right)^{2}+0.143\right)$ & 14.8 \\
\hline $\mathrm{CoCl}_{2} \cdot 6 \mathrm{H}_{2} \mathrm{O}$ & $\mid \begin{array}{c}\mathrm{Ni}^{2+}, \mathrm{Mg}^{2+} \\
\mathrm{Zn}^{2+}, \mathrm{Co}^{2+} \\
\mathrm{Cu}^{2+}, \mathrm{Mn}^{2+} \\
\mathrm{Cd}^{2+}, \mathrm{Ca}^{2+} \\
\mathrm{Sr}^{2+}\end{array}$ & 9 & $D_{2 / 1}=\exp \left(0.0078 \eta^{3}-1.42|\Delta h|+0.32 \Delta s-2.92\right)$ & 27.0 \\
\hline alums & $\left|\begin{array}{c}\mathrm{Al}^{3+}, \mathrm{Fe}^{3+} \\
\mathrm{Cr}^{3+}\end{array}\right|$ & 9 & $D_{2 / 1}=\left(\frac{m_{01}}{m_{02}}\right)^{2} \cdot \exp (16.85 \cdot \eta-130.2)$ & 29.8 \\
\hline \begin{tabular}{c|}
$\mathrm{M}_{2}$ \\
$\mathrm{M}^{\mathrm{II}}\left(\mathrm{SO}_{4}\right)_{2} \cdot 6 \mathrm{H}_{2} \mathrm{O}$ \\
$\mathrm{M}^{\mathrm{I}^{\prime}}=\left\{\mathrm{NH}_{4}^{+}, \mathrm{Rb}^{+}\right\}$ \\
\end{tabular} & \begin{tabular}{|c|}
$\mathrm{Na}^{+}, \mathrm{K}^{+}$ \\
$\mathrm{Rb}^{+}, \mathrm{Cs}^{+}$ \\
$\mathrm{Tl}^{+}$ \\
\end{tabular} & 7 & $D_{2 / 1}=\left(\frac{m_{01}}{m_{02}}\right)^{1.25} \cdot \exp (1.48 \cdot \eta-10.2)$ & 9.1 \\
\hline $\begin{array}{c}\mathrm{M}_{2} \\
\mathrm{M}^{\mathrm{II}}\left(\mathrm{SO}_{4}\right)_{2} \cdot 6 \mathrm{H}_{2} \mathrm{O} \\
\mathrm{M}^{\mathrm{I}}=\{\mathrm{Ni}, \mathrm{Mg}, \mathrm{Cu} \\
\mathrm{Co}, \mathrm{Zn}, \mathrm{Fe}, \mathrm{Mn}\}\end{array}$ & $\begin{array}{c}\mathrm{Ni}^{2+}, \mathrm{Mg}^{2+} \\
\mathrm{Zn}^{2+} \\
\mathrm{Mn}^{2+}, \mathrm{Co}^{2+} \\
\mathrm{Cu}^{2+}, \mathrm{Cd}^{2+}\end{array}$ & 43 & $D_{2 / 1}=\left(\frac{m_{01}}{m_{02}}\right)^{2.5} \cdot \exp \left(0.835 \cdot \frac{1}{r_{2}^{2}}-0.082\right)$ & 25.9 \\
\hline $\begin{array}{c}\mathrm{M}^{\prime}(\mathrm{HCOO})_{2} \cdot 2 \mathrm{H}_{2} \mathrm{O} \\
\mathrm{M}^{\prime}=\{\mathrm{Ni}, \mathrm{Mg}, \mathrm{Co} \\
\mathrm{Zn}, \mathrm{Fe}, \mathrm{Mn}, \mathrm{Cd}\}\end{array}$ & $\begin{array}{c}\mathrm{Ni}^{2+}, \mathrm{Mg}^{2+} \\
\mathrm{Zn}^{2+} \\
\mathrm{Mn}^{2+}, \mathrm{Co}^{2+} \\
\mathrm{Cu}^{2+}, \mathrm{Cd}^{2+}\end{array}$ & 37 & $D_{2 / 1}=\left(\frac{m_{01}}{m_{02}}\right)^{3} \cdot \exp \left(\begin{array}{l}1.67 \frac{\eta_{1}^{3}-\eta_{2}^{3}}{\eta_{1}^{3}}+1.37 \Delta \varepsilon- \\
-0.057 \Delta h+1.65 \Delta s+0.153\end{array}\right)$ & 31.0 \\
\hline $\begin{array}{l}\mathrm{M}_{2}^{\prime} \mathrm{SO}_{4} \cdot \mathrm{nH}_{2} \mathrm{O} \\
\mathrm{M}^{\prime}=\{\mathrm{Na}, \mathrm{K}, \mathrm{Tl}\}\end{array}$ & \begin{tabular}{|c|}
$\mathrm{Na}^{+}, \mathrm{K}^{+}$ \\
$\mathrm{Rb}^{+}, \mathrm{Cs}^{+}$ \\
$\mathrm{Tl}^{+}$ \\
\end{tabular} & 9 & $D_{2 / 1}=\exp \left(12.88 \frac{1}{r_{2}^{2}}-4.829 \Delta \varepsilon-7,684\right)$ & $\begin{array}{c}22.8 \\
(4)\end{array}$ \\
\hline $\begin{array}{c}\mathrm{MX} \\
\mathrm{X}=\{\mathrm{Cl}, \mathrm{Br}, \mathrm{I}\}\end{array}$ & $\mid \begin{array}{c}\mathrm{Cs}^{+}, \mathrm{Rb}^{+} \\
\mathrm{K}^{+}\end{array}$ & 9 & $D_{2 / 1}=\left(\frac{m_{01}}{m_{02}}\right)^{2} \cdot \exp \left(-132.8\left(\frac{r_{1}-r_{2}}{r_{1}}\right)^{2}+4.38 \Delta h+0.072\right)$ & $\begin{array}{c}29.3 \\
(4)\end{array}$ \\
\hline $\begin{array}{c}\mathrm{MNO}_{3} \\
\mathrm{M}^{\prime}=\{\mathrm{K}, \mathrm{Rb}, \mathrm{Cs}\}\end{array}$ & $\begin{array}{c}\mathrm{Cs}^{+}, \mathrm{Rb}^{+} \\
\mathrm{K}^{+}\end{array}$ & 5 & $D_{2 / 1}=\exp \left(-16.57 \frac{1}{r_{2}}-349.4(\Delta \varepsilon)^{2}+9,209\right)$ & 18.9 \\
\hline
\end{tabular}

Table 12. Part 1. Some examples of the estimation of coefficients $D_{2 / 1}($ Smolik, 2004) 


\begin{tabular}{|c|c|c|c|c|}
\hline $\begin{array}{c}\mathrm{MClO}_{3} \\
\mathrm{M}^{\prime}=\{\mathrm{K}, \mathrm{Rb}\}\end{array}$ & $\begin{array}{c}\mathrm{Cs}^{+}, \mathrm{Rb}^{+}, \\
\mathrm{K}^{+}\end{array}$ & 3 & $D_{2 / 1}=\left(\frac{m_{01}}{m_{02}}\right)^{2} \cdot \exp \left(-4.282 \cdot r_{2}+4.074\right)$ & 5.3 \\
\hline $\begin{array}{c}\mathrm{MClO}_{4} \\
\mathrm{M}^{\prime}=\{\mathrm{K}, \mathrm{Rb}, \mathrm{Cs}\}\end{array}$ & $\begin{array}{c}\mathrm{Cs}^{+}, \mathrm{Rb}^{+}, \\
\mathrm{K}^{+}\end{array}$ & 5 & $D_{2 / 1}=\left(\frac{m_{01}}{m_{02}}\right)^{2} \cdot \exp \left(\begin{array}{l}-74.20 \cdot\left(\frac{r_{1}-r_{2}}{r_{1}}\right)^{2}+ \\
+2.345 \Delta h-0,185\end{array}\right)$ & 26.5 \\
\hline $\begin{array}{c}\mathrm{M}_{2} \mathrm{CrO}_{4} \\
\mathrm{M}^{\prime}=\{\mathrm{K}, \mathrm{Rb}, \mathrm{Cs}\}\end{array}$ & $\begin{array}{l}\mathrm{Cs}^{+}, \mathrm{Rb}^{+}, \\
\mathrm{K}^{+}\end{array}$ & 4 & $D_{2 / 1}=\left(\frac{m_{01}}{m_{02}}\right)^{2} \cdot \exp \left(-7.967 \cdot\left(\frac{r_{1}-r_{2}}{r_{1}}\right)-0.424\right.$ & 5.1 \\
\hline
\end{tabular}

(1) $-\mathrm{M}^{\mathrm{n}+}$ is not microcomponent, when $\mathrm{M}^{\prime}=\mathrm{M}$;

(2) - subscripts " 1 " and "2" relate to macrocomponent and microcomponent respectively;

(3) $-\eta=10^{8} \sqrt[3]{\frac{M}{D_{x} N}}[\AA ̊]$, where $\mathrm{M}$ - molar mass of salt $[\mathrm{g} / \mathrm{mol}], \mathrm{D}_{\mathrm{x}}-$ its density $\left[\mathrm{g} / \mathrm{cm}^{3}\right]$,

$\mathrm{N}$ - Avogadro number $\left[6.022 \cdot 10^{23} / \mathrm{mol}\right]$;

(4) - in this case $\left|\left(r_{1}-r_{2}\right) / r_{1}\right|<0.20$ (for the other cases $\left.D_{2 / 1}<0.06\right) ; k$ - number of crystallizations systems (macrocomponent $)_{\mathrm{j}}$ - (microcomponent $)_{\mathrm{ji}}$ in a given group of salt.

Table 12. Part 2. Some examples of the estimation of coefficients $D_{2 / 1}($ Smolik, 2004)

\section{Methods of lowering $D_{2 / 1}$ values as the way of increasing purification efficiency of crystallization}

From the practical point of view it is very interesting to ascertain how to increase the efficiency of crystallization purification of inorganic substances. This is possible when cocrystallization coefficients $\mathrm{D}_{2 / 1}$ can be lowered. They depend generally, as shown above, on chemical, physicochemical and crystal-chemical properties of co-crystallizing salts and ions. However, there are some previously mentioned "external" factors (such as the kind and composition of the solvent - the liquid phase, the presence of ions or other foreign substances, the presence of complexing agents, acidity $[\mathrm{pH}]$ of the solution, from which crystallization takes place, temperature) which may influence these coefficients. Their effect on $\mathrm{D}_{2 / 1}$ coefficients will be discussed below.

\subsection{The effect of the kind and composition of the solvent - the liquid phase}

The change of composition of the solvent, from which the crystallization takes place, alternates solubilities of co-crystallizing salts, as well as activity coefficients of all components in the liquid phase and indirectly in the solid phase.

Because of decreased water activity, the formed crystal hydrates have a lower number of molecules of crystallization water of different structures, which may influence the similarity of the crystal structure of macro and microcomponents. All these mentioned factors vary in different directions and to a different degree, and therefore, they may finally cause the change of co-crystallization coefficients. Examples are given in Table $\mathbf{1 3 .}$ 


\begin{tabular}{|c|c|c|c|c|c|c|c|c|c|c|}
\hline \multicolumn{6}{|c|}{ Composition of the mother solution [\% v/v] } & \multicolumn{5}{|c|}{ Co-crystallization coefficients $\mathrm{D}_{2 / 1}$} \\
\hline $\mathrm{H}_{2} \mathrm{O}$ & $\begin{array}{l}\text { iso- } \\
\mathrm{PrOH}\end{array}$ & $\mathrm{CH}_{3} \mathrm{OH}$ & $\mathrm{C}_{2} \mathrm{H}_{5} \mathrm{OH}$ & $\mathrm{Et}_{2} \mathrm{O}$ & $\mathrm{Me}_{2} \mathrm{CO}$ & $\mathrm{Mg}^{2+}$ & $\mathrm{Co}^{2+}$ & $\mathrm{Fe}^{2+}$ & $\mathrm{Mn}^{2+}$ & $\mathrm{Cu}^{2+}$ \\
\hline 100 & & & & & & $\begin{array}{c}0.50 \pm \\
0.04\end{array}$ & $\begin{array}{c}0.96 \pm \\
0.07\end{array}$ & $\begin{array}{c}0.60 \pm \\
0.05\end{array}$ & $\begin{array}{c}0.22 \pm \\
0.02\end{array}$ & $\begin{array}{c}0.21 \pm \\
0.02\end{array}$ \\
\hline 50 & 20 & 30 & & & & $\begin{array}{c}0.42 \pm \\
0.04 \\
\end{array}$ & $\begin{array}{c}0.80 \pm \\
0.06 \\
\end{array}$ & $\begin{array}{c}0.31 \pm \\
0.03 \\
\end{array}$ & $\begin{array}{c}0.10 \pm \\
0.01 \\
\end{array}$ & $\begin{array}{c}0.14 \pm \\
0.01 \\
\end{array}$ \\
\hline 60 & & & 38 & 2 & & $\begin{array}{c}0.39 \pm \\
0.03 \\
\end{array}$ & $\begin{array}{c}0.96 \pm \\
0.07\end{array}$ & $\begin{array}{c}0.46 \pm \\
0.05\end{array}$ & $\begin{array}{c}0.14 \pm \\
0.01 \\
\end{array}$ & $\begin{array}{c}0.17 \pm \\
0.02 \\
\end{array}$ \\
\hline 63 & & & & & 37 & $\begin{array}{c}0.57 \pm \\
0.05\end{array}$ & $\begin{array}{c}0.70 \pm \\
0.06\end{array}$ & $\begin{array}{c}0.49 \pm \\
0.04\end{array}$ & $\begin{array}{c}0.18 \pm \\
0.02\end{array}$ & $\begin{array}{c}0.15 \pm \\
0.02\end{array}$ \\
\hline
\end{tabular}

Table 13. The effect of addition of various organic solvents: iso-propyl alcohol (iso-PrOH), methanol $\left(\mathrm{CH}_{3} \mathrm{OH}\right)$, ethanol $\left(\mathrm{C}_{2} \mathrm{H}_{5} \mathrm{OH}\right)$, diethyl ether $\left(\mathrm{Et}_{2} \mathrm{O}\right)$, acetone $\left(\mathrm{Me}_{2} \mathrm{CO}\right)$ on coefficients $\mathrm{D}_{2 / 1}$ during the crystallization of $\mathrm{NiSO}_{4} \cdot 7 \mathrm{H}_{2} \mathrm{O}$ at $25{ }^{\circ} \mathrm{C}$ (Smolik, 1984)

\subsection{The effect of the presence of other ions or substances in the liquid phase}

Interactions which happen in the aqueous phase may also influence $\mathrm{D}_{2 / 1}$ coefficients. This effect is formally taken into consideration in equation (19) by the mean activity coefficients of both the macrocomponent $\left(\gamma_{\mathrm{m} 1}\right)$ and microcomponent $\left(\gamma_{\mathrm{m} 2}\right)$.

If the action of various factors in aqueous solution causes the same changes in both mean activity coefficients, so that $\frac{\gamma_{m 1}}{\gamma_{m 2}}=$ const. , then at unchanged properties of the solid phase $\mathrm{D}_{2 / 1}$ coefficient remains constant (e.g., the addition of $\mathrm{HBr}$ during the co-crystallization of $\mathrm{Ra}^{2+}$ with $\mathrm{BaBr}_{2}$ does not affect $\mathrm{D}_{2 / 1}$ coefficient, likewise the introduction of weak electrolytes (glucose or $\mathrm{CH}_{3} \mathrm{COONa}+\mathrm{CH}_{3} \mathrm{COOH}$ ) having no common ions with micro and macrocomponent $\left(\mathrm{Ra}\left(\mathrm{NO}_{3}\right)_{2}\right.$ i $\left.\mathrm{Ba}\left(\mathrm{NO}_{3}\right)_{2}\right)$ and not reacting with them also does not change the $\mathrm{D}_{2 / 1}$ value (Chlopin, 1938).

However, if substances are present in the solution that react in a different way with the macro and microcomponent ions forming slightly dissociated compounds, an essential change of $\mathrm{D}_{2 / 1}$ coefficients takes place (e.g., the addition of $\mathrm{CH}_{3} \mathrm{COONa}+\mathrm{CH}_{3} \mathrm{COOH}$ in the crystallization system $\mathrm{Pb}\left(\mathrm{NO}_{3}\right)_{2}-\mathrm{Ra}\left(\mathrm{NO}_{3}\right)_{2}-\mathrm{H}_{2} \mathrm{O}$ causes bonding a part of $\mathrm{Pb}^{2+}$ ions in slightly dissociated acetate, which leads to the lowering of its mean activity coefficient and finally to the increase of radium co-crystallization coefficient (Chlopin, 1938).

\subsection{The effect of the presence of complexing agents}

The presence of complexing agents has a significant influence on coefficient, $\mathrm{D}_{2 / 1}$. In the case of forming complexes by both macrocomponent and microcomponent, the relationship between the value of co-crystallization coefficient in the presence of complexing agent $\left(D_{2 / 1}\right)^{k}$ and that in the case of its absence $\left(D_{2 / 1}\right)$ is expressed by equation (Mikheev et al., 1962): $D_{2 / 1}^{k}=D_{2 / 1} \cdot \frac{1+\frac{[M L]}{[M]}}{1+\frac{\beta}{\beta^{\prime}} \cdot \frac{[M L]}{[M]}}$, where $\beta\left(\beta^{\prime}\right)$ - stability constant of the complex of 
microcomponent (macrocomponent), $[\mathrm{ML}]$ and $[\mathrm{M}]$ are the concentrations of macrocomponent complexes and its free ions. Hence if $\beta / \beta^{\prime}>1$ (stability of the complex with microcomponent is higher), then $\mathrm{Dk}_{2 / 1}<\mathrm{D}_{2 / 1}$ (microcomponent co-crystallizes to a lower degree and vice versa.

An example of the use of a complexing agent to significantly lower $D_{2 / 1}$ coefficients is presented in Table 14.

The presence of EDTA4- in stoichiometric amount causes 4 - 180 fold lowering of $\mathrm{D}_{2 / 1}$ coefficients of $\mathrm{M}^{2+}$ and $\mathrm{M}^{3+}$ ions, because of the formation of $[\mathrm{M}(\mathrm{EDTA})]^{2-}$ or [M(EDTA)]anionic complexes, and in the case of some of them $\left(\mathrm{Cd}^{2+}, \mathrm{Mn}^{2+}, \mathrm{Ni}^{2+}, \mathrm{Al}^{3+}\right.$ and $\left.\mathrm{Cr}^{3+}\right)$ twofold increase of EDTA4- excess leads to an additional drop of $\mathrm{D}_{2 / 1}$ coefficients.

\begin{tabular}{|c|c|c|c|}
\hline \multirow{3}{*}{ Ions } & \multicolumn{3}{|c|}{ Co-crystallization coefficients, $\mathrm{D}_{2 / 1}$} \\
\cline { 2 - 4 } & \multicolumn{3}{|c|}{$\begin{array}{r}\text { Ratio of the number of moles of EDTA4- to the sum of the number of } \\
\text { moles of } \mathrm{M}^{2+} \text { and } \mathrm{M}^{3+} \text { ions before crystallization }\end{array}$} \\
\cline { 2 - 4 } & $0: 1$ & $1: 1$ & $2: 1$ \\
\hline $\mathrm{Fe}^{3+}$ & 2.24 & 0.02 & 0.02 \\
\hline $\mathrm{Co}^{2+}$ & 0.21 & 0.01 & 0.01 \\
\hline $\mathrm{Zn}^{2+}$ & 0.18 & $<0.01$ & $<0.01$ \\
\hline $\mathrm{Cd}^{2+}$ & 1.40 & 0.10 & $<0.01$ \\
\hline $\mathrm{Mn}^{2+}$ & 1.08 & 0.27 & 0.07 \\
\hline $\mathrm{Ni}^{2+}$ & 0.19 & 0.01 & 0.01 \\
\hline $\mathrm{Cu}^{2+}$ & 0.28 & 0.01 & 0.01 \\
\hline $\mathrm{Al}^{3+}$ & 0.46 & 0.05 & 0.01 \\
\hline $\mathrm{Cr}^{3+}$ & 1.92 & 0.16 & 0.03 \\
\hline
\end{tabular}

Table 14. The effect of EDTA4- addition on $\mathrm{D}_{2 / 1}$ coefficients of co-crystallization of $\mathrm{M}^{2+} \mathrm{i} \mathrm{M}^{3+}$ ions with $\mathrm{Na}_{2} \mathrm{SO}_{4}$ at $50{ }^{\circ} \mathrm{C}$. (1998b)

\subsection{The effect of the acidity $(\mathrm{pH})$ of the solution, from which crystallization takes place}

Cations of macrocomponent $\left(\left[\mathrm{M}\left(\mathrm{H}_{2} \mathrm{O}\right)_{\mathrm{x}}\right]^{\mathrm{n}+}\right)$ and microcomponent $\left(\left[\mathrm{M}^{\prime}\left(\mathrm{H}_{2} \mathrm{O}\right)_{\mathrm{x}^{\prime}}\right]^{\mathrm{n+}}\right)$ present in the solution, from which crystallization usually takes place, may hydrolyze according to the following equations: $\left[\mathrm{M}\left(\mathrm{H}_{2} \mathrm{O}\right)_{\mathrm{x}}\right]^{\mathrm{n}+}+\mathrm{H}_{2} \mathrm{O} \leftrightarrows\left[\mathrm{M}\left(\mathrm{H}_{2} \mathrm{O}\right)_{\mathrm{x}-1}(\mathrm{OH})\right]^{(\mathrm{n}-1)^{+}+} \mathrm{H}_{3} \mathrm{O}^{+}$and $\left[\mathrm{M}^{\prime}\left(\mathrm{H}_{2} \mathrm{O}\right)_{\mathrm{x}^{\prime}}\right]^{\mathrm{n}+}$ $+\mathrm{H}_{2} \mathrm{O} \leftrightarrows\left[\mathrm{M}^{\prime}\left(\mathrm{H}_{2} \mathrm{O}\right)_{\mathrm{x}^{\prime}-1}(\mathrm{OH})\right]^{(\mathrm{n}-1)^{+}}+\mathrm{H}_{3} \mathrm{O}^{+}$. The degree of hydrolysis depends on $\left[\mathrm{M}\left(\mathrm{H}_{2} \mathrm{O}\right)_{\mathrm{x}}\right]^{\mathrm{n}+}$ $\left(\left[\mathrm{M}^{\prime}\left(\mathrm{H}_{2} \mathrm{O}\right)_{\mathrm{x}^{\prime}}\right]^{\mathrm{n}+}\right)$ cation acidic strength, meant as Brönstedt acid

$\left(\mathrm{K}_{\mathrm{hi}}=\left\{\left[\mathrm{M}\left(\mathrm{H}_{2} \mathrm{O}\right)_{\mathrm{x}-1}(\mathrm{OH})\right]^{(\mathrm{n}-1)+}\right\} \cdot\left\{\mathrm{H}_{3} \mathrm{O}^{+}\right\} /\left\{\left[\mathrm{M}\left(\mathrm{H}_{2} \mathrm{O}\right)_{\mathrm{x}}\right]^{\mathrm{n}+}\right\}\right.$. If the difference in $\mathrm{K}_{\mathrm{h}}$ of both ions is significant (e.g., $\left.\mathrm{K}_{\mathrm{h} 2}>>\mathrm{K}_{\mathrm{h} 1}\right)$, ions $\left(\left[\mathrm{M}^{\prime}\left(\mathrm{H}_{2} \mathrm{O}\right)_{x^{\prime}-1}(\mathrm{OH})\right]^{(\mathrm{n}-1)+}\right)$ of different charge than those of macrocomponent $\left(\left[\mathrm{M}\left(\mathrm{H}_{2} \mathrm{O}\right)_{\times}\right]^{\mathrm{n}+}\right)$ are present in the solution, which in-build into crystals of macrocomponent to a lower degree (e.g., $\mathrm{D}_{\mathrm{Fe}(\mathrm{III}) / \mathrm{NH} 4 \mathrm{Al} \text { alum }}=0.038 \pm 0.005$ in $0,1 \mathrm{M} \mathrm{H}_{2} \mathrm{SO}_{4}$ solution and $\mathrm{D}_{\mathrm{Fe}(\mathrm{III}) / \mathrm{NH} 4 \mathrm{Al} \text { alum }}=0.063 \pm 0.009$ in $1,0 \mathrm{M} \mathrm{H}_{2} \mathrm{SO}_{4}$ solution) (Smolik, 1995b).

In the case of $\mathrm{NiCl}_{2} \cdot 6 \mathrm{H}_{2} \mathrm{O}$ crystallization with increasing $\mathrm{HCl}$ concentration, the lowering of co-crystallization coefficients $\mathrm{D}_{2 / 1}$ of $\mathrm{Co}^{2+}, \mathrm{Mn}^{2+}, \mathrm{Cu}^{2+}$ and $\mathrm{Fe}^{2+}$ (Table 15) is caused not only by the rise of acidity of the solution, but also by the formation of chloride complexes at higher $\mathrm{Cl}^{-}$concentrations. A significant decrease of $\mathrm{Mn}^{2+}$ coefficient $\left(\mathrm{D}_{\mathrm{Mn}}\right)$ occurs even at 0.5 $\mathrm{M} \mathrm{HCl}$, but that of $\mathrm{Fe}^{2+}$ and $\mathrm{Co}^{2+}$ only at $5 \mathrm{M} \mathrm{HCl}$. 


\begin{tabular}{|c|c|c|c|}
\hline \multirow{2}{*}{ Microcomponent } & \multicolumn{3}{|c|}{ Average $\mathrm{D}_{2 / 1}$ coefficients for $\mathrm{HCl}$ concentrations [mol/L] } \\
\cline { 2 - 4 } & 0 & 0.5 & 5 \\
\hline $\mathrm{Co}^{2+}$ & $2.60 \pm 0.30$ & $2.30 \pm 0.30$ & $1.80 \pm 0.10$ \\
\hline $\mathrm{Mn}^{2+}$ & $0.46 \pm 0.02$ & $0.20 \pm 0.02$ & $0.21 \pm 0.01$ \\
\hline $\mathrm{Cu}^{2+}$ & $0.04 \pm 0.01$ & $0.04 \pm 0.01$ & $0.02 \pm 0.01$ \\
\hline $\mathrm{Fe}^{2+}$ & $1.70 \pm 0.20$ & $1.20 \pm 0.20$ & $0.40 \pm 0.08$ \\
\hline
\end{tabular}

Table 15. The effect of $\mathrm{HCl}$ concentration on $\mathrm{D}_{2 / 1}$ coefficients of some $\mathrm{M}^{2+}$ ions during the crystallization of $\mathrm{NiCl}_{2} \cdot 6 \mathrm{H}_{2} \mathrm{O}$ at $25{ }^{\circ} \mathrm{C}$ (Smolik, 1999b)

\subsection{The effect of the change of the oxidation state}

In some cases it is possible to change easily the oxidation state of the microcomponent or macrocomponent during or before crystallization. Usually this is accompanied by a significant alteration of $\mathrm{D}_{2 / 1}$ coefficients, which may be utilized for the rise of purification efficiency. Several examples of the change of microcomponent oxidation state are presented in Table 16.

\begin{tabular}{|c|c|c|c|c|c|}
\hline \multirow[b]{2}{*}{$\begin{array}{l}\text { Crystallized salt } \\
\text { temperature }\end{array}$} & \multicolumn{2}{|c|}{ Oxidation state of } & \multirow{2}{*}{$\begin{array}{c}\text { Factor } \\
\text { changing } \\
\text { oxidation state }\end{array}$} & \multirow[b]{2}{*}{$\mathrm{D}_{2 / 1}$} & \multirow[b]{2}{*}{ Ref. } \\
\hline & $\begin{array}{c}\text { Macro- } \\
\text { component }\end{array}$ & $\begin{array}{c}\text { Micro- } \\
\text { component }\end{array}$ & & & \\
\hline \multirow{2}{*}{$\begin{array}{c}\mathrm{MnSO}_{4} \cdot 5 \mathrm{H}_{2} \mathrm{O} \\
\text { at } 20{ }^{\circ} \mathrm{C}\end{array}$} & \multirow{2}{*}{$\mathrm{Mn}^{2+}$} & $\mathrm{Fe}^{2+}$ & \multirow{2}{*}{$\mathrm{H}_{2} \mathrm{O}_{2}$} & 1.04 & \multirow{2}{*}{$\begin{array}{c}\text { (Smolik } \\
\text { et al., } \\
1995)\end{array}$} \\
\hline & & $\mathrm{Fe}^{3+}$ & & $<0.03$ & \\
\hline \multirow{2}{*}{$\begin{array}{c}\mathrm{CoSO}_{4} \cdot 7 \mathrm{H}_{2} \mathrm{O} \\
\text { at } 20^{\circ} \mathrm{C}\end{array}$} & \multirow{2}{*}{$\mathrm{Co}^{2+}$} & $\mathrm{Fe}^{2+}$ & \multirow{2}{*}{$\mathrm{H}_{2} \mathrm{O}_{2}$} & 1.20 & \multirow{2}{*}{$\begin{array}{c}\text { (Smolik, } \\
\text { 2003) }\end{array}$} \\
\hline & & $\mathrm{Fe}^{3+}$ & & $<0.03$ & \\
\hline \multirow{2}{*}{$\begin{array}{c}\mathrm{NH}_{4} \mathrm{Al}\left(\mathrm{SO}_{4}\right)_{2} \cdot 12 \mathrm{H}_{2} \mathrm{O} \\
\text { at } 25{ }^{\circ} \mathrm{C}\end{array}$} & \multirow{2}{*}{$\mathrm{Al}^{3+}$} & $\mathrm{Fe}^{3+}$ & \multirow{2}{*}{$\mathrm{NH}_{2} \mathrm{OH} . \mathrm{H}_{2} \mathrm{SO}_{4}$} & $\begin{array}{c}0.04 \pm \\
0.01\end{array}$ & \multirow{2}{*}{$\begin{array}{l}\text { (Smolik, } \\
\text { 1995b) }\end{array}$} \\
\hline & & $\mathrm{Fe}^{2+}$ & & $<0.01$ & \\
\hline
\end{tabular}

Table 16. The effect of the change of oxidation state of microcomponent on $\mathrm{D}_{2 / 1}$ coefficients

The change of the oxidation state of macrocomponent can be used for the purification of iron salts: crystallization of $\mathrm{FeSO}_{4} 7 \mathrm{H}_{2} \mathrm{O}$ at $20{ }^{\circ} \mathrm{C}$ permits, with great efficiency, removal of all $\mathrm{M}^{+}$and $\mathrm{M}^{3+}$ ions (Fig. 12a) and the remaining $\mathrm{M}^{2+}$ ions can be easily removed after transferring $\mathrm{FeSO}_{4} \cdot 7 \mathrm{H}_{2} \mathrm{O}$ into $\mathrm{NH}_{4} \mathrm{Fe}\left(\mathrm{SO}_{4}\right)_{2} \cdot 12 \mathrm{H}_{2} \mathrm{O}$ by oxidation and its crystallization at 20 ${ }^{\circ} \mathrm{C}$ (Fig. 12b).

\subsection{The effect of temperature}

The effect of temperature on $\mathrm{D}_{2 / 1}$ coefficients is very complex. As temperature increases, the solubilities of the macro and microcomponent $\left(\mathrm{m}_{01}, \mathrm{~m}_{02}\right)$, the mean activity coefficients in their binary saturated solutions $\left(\gamma_{\mathrm{m} 01}, \gamma_{\mathrm{m} 02}\right)$, the mean activity coefficients in the ternary solution being in equilibrium with their mixed crystal $\left(\gamma_{\mathrm{m} 1}, \gamma_{\mathrm{m} 2}\right)$ (temperature affects dehydration of ions, processes of hydrolysis or complex formation in solution (Kirkova et al., 1996), as well as activity coefficients of both in their solid solution $\left(f_{1}, f_{2}\right)$ (temperature influences enthalpy of mixing in the solid phase) change in different directions in various crystallization systems. Therefore, both the increase and drop of co-crystallization coefficient 
may be observed or sometimes the maintenance of its constant value (in the case of compensation of the all mentioned changes). However, the alteration of $\mathrm{D}_{2 / 1}$ runs generally in a continuous manner as long as there are no phase transitions. If a phase transition in the system takes place, a jump change of $\mathrm{D}_{2 / 1}$ appears, connected with the transition from isomorphous co-crystallization into the isodimorphous one. The determination of temperatures at which such a jump change of co-crystallization coefficients takes place, permits finding the temperatures of the phase transitions for many hydrate sulfates (Purkayastha \& Das, 1972, 1975), as well as predicting the existence (at specific conditions) of hydrates of some salts, as yet unknown (Purkayastha \& Das, 1971).

Some examples of the changes of co-crystallization coefficients $\mathrm{D}_{2 / 1}$ at various temperatures have been presented in Table 17.

\begin{tabular}{|c|c|c|c|c|c|c|}
\hline \multirow{2}{*}{$\begin{array}{c}\text { (macro- } \\
\text { compo- } \\
\text { nent) }\end{array}$} & \multirow[b]{2}{*}{ ion } & \multirow{2}{*}{$\begin{array}{c}\text { Tempe- } \\
\text { rature } \\
{\left[{ }^{\circ} \mathrm{C}\right]}\end{array}$} & \multicolumn{2}{|c|}{ Kind of hydrate (crystal structure) of } & \multirow[b]{2}{*}{$\mathrm{D}_{2 / 1}$} & \multirow[b]{2}{*}{ Ref. } \\
\hline & & & $\begin{array}{c}\text { Macro- } \\
\text { component }\end{array}$ & $\begin{array}{c}\text { Micro- } \\
\text { component }\end{array}$ & & \\
\hline \multirow{2}{*}{$\mathrm{MnSO}_{4}$} & \multirow{2}{*}{$\mathrm{Cu}^{2+}$} & 20 & $\mathrm{MnSO}_{4} \cdot 5 \mathrm{H}_{2} \mathrm{O}$ (tcl.) & $\mathrm{CuSeO}_{4} \cdot 5 \mathrm{H}_{2} \mathrm{O}$ (tcl.) & 1.63 & \multirow{2}{*}{$\begin{array}{c}\text { (Smolik, } \\
\text { 2004) }\end{array}$} \\
\hline & & 50 & $\mathrm{MnSO}_{4} \cdot \mathrm{H}_{2} \mathrm{O}$ (mcl.) & $\mathrm{CuSeO}_{4} \cdot 5 \mathrm{H}_{2} \mathrm{O}$ (tcl.) & 0.15 & \\
\hline \multirow{5}{*}{$\mathrm{ZnSeO}_{4}$} & \multirow{3}{*}{$\mathrm{Cu}^{2+}$} & 25 & $\mathrm{ZnSeO}_{4} \cdot 6 \mathrm{H}_{2} \mathrm{O}$ (tetr.) & $\mathrm{CuSeO}_{4} \cdot 5 \mathrm{H}_{2} \mathrm{O}$ (tcl.) & 0.51 & \multirow{5}{*}{$\begin{array}{c}\text { (Smolik \& } \\
\text { Kowalik, } \\
2010,2011)\end{array}$} \\
\hline & & 40 & $\mathrm{ZnSeO}_{4} \cdot 5 \mathrm{H}_{2} \mathrm{O}$ (tcl.) & $\mathrm{CuSeO}_{4} \cdot 5 \mathrm{H}_{2} \mathrm{O}$ (tcl.) & 1.77 & \\
\hline & & 50 & $\mathrm{ZnSeO}_{4} \cdot \mathrm{H}_{2} \mathrm{O}$ (mcl.) & $\mathrm{CuSeO}_{4} \cdot 5 \mathrm{H}_{2} \mathrm{O}$ (tcl.) & 0.12 & \\
\hline & \multirow{2}{*}{$\mathrm{Ni}^{2+}$} & 25 & $\mathrm{ZnSeO}_{4} \cdot 6 \mathrm{H}_{2} \mathrm{O}$ (tetr.) & $\mathrm{NiSeO}_{4} \cdot 6 \mathrm{H}_{2} \mathrm{O}$ (tetr.) & 2.93 & \\
\hline & & 40 & $\mathrm{ZnSeO}_{4} \cdot 5 \mathrm{H}_{2} \mathrm{O}$ (tcl.) & $\mathrm{NiSeO}_{4} \cdot 6 \mathrm{H}_{2} \mathrm{O}$ (tetr.) & 0.21 & \\
\hline \multirow{2}{*}{$\mathrm{Sr}\left(\mathrm{NO}_{3}\right)_{2}$} & \multirow{2}{*}{$\mathrm{Pb}^{2+}$} & 29 & $\mathrm{Sr}\left(\mathrm{NO}_{3}\right)_{2} \cdot 4 \mathrm{H}_{2} \mathrm{O}(\mathrm{mcl})$. & $\mathrm{Pb}\left(\mathrm{NO}_{3}\right)_{2}$ (cub.) & 0.66 & \multirow{2}{*}{$\begin{array}{l}\text { (Niesmie- } \\
\text { anov, 1975) }\end{array}$} \\
\hline & & 34 & $\mathrm{Sr}\left(\mathrm{NO}_{3}\right)_{2}$ (cub.) & $\mathrm{Pb}\left(\mathrm{NO}_{3}\right)_{2}$ (cub.) & 3.30 & \\
\hline \multirow{2}{*}{$\mathrm{Na}_{2} \mathrm{SO}_{4}$} & \multirow{2}{*}{$\mathrm{Fe}^{3+}$} & 25 & $\mathrm{Na}_{2} \mathrm{SO}_{4}$ (rhomb.) & & 0.01 & \multirow{2}{*}{$\begin{array}{c}\text { (Smolik, } \\
\text { 1998b) }\end{array}$} \\
\hline & & 50 & $\mathrm{Na}_{2} \mathrm{SO}_{4} \cdot 10 \mathrm{H}_{2} \mathrm{O}(\mathrm{mcl}$. $)$ & & 2.24 & \\
\hline
\end{tabular}

Table 17. The effect of temperature on $\mathrm{D}_{2 / 1}$ coefficients

The observation of the alterations of $\mathrm{D}_{2 / 1}$ coefficients with changing temperature sometimes permits finding such ranges of this parameter, where they are low enough that crystallization purification of the macrocomponent from a given microcomponent will be very effective (Purkayastha \& Das, 1972; Smolik \& Kowalik, 2010, 2011). In such a manner it turned out to be possible to accomplish essential purification of $\mathrm{CoSeO}_{4}$ from almost all $\mathrm{M}^{2+}$ ions (most difficult to remove) solely by the crystallization method (Kowalik et al., 2011).

\section{Conclusions}

Crystallization of substances from solutions seems still to be a convenient method of their purification, particularly in obtaining of high purity inorganic compounds. The effectiveness of this process depends on the kind of both macrocomponent (1) and microcomponent (2) and can be evaluated by means of co-crystallization coefficient, $\mathrm{D}_{2 / 1}$ (Henderson - Kraček, Chlopin). These coefficients are affected by conditions applied in the crystallization process, but those which are equilibrium ones, depend exclusively on "internal" and "external" factors.

"Internal" factors (resulting from chemical, physicochemical and crystal-chemical properties of co-crystallizing salts and ions to a significant degree) determine the level of $D_{2 / 1}$ 
coefficients. The investigation involving the effect of these factors is of great importance because it makes it possible to evaluate the usefulness of crystallization in the separation of a given pair of macrocomponent (1) and microcomponent (2).

By means of "external" factors a significant lowering of $\mathrm{D}_{2 / 1}$ coefficients is sometimes possible, and thus, the improvement of the efficiency of crystallization purification.

Growing knowledge concerning coefficients $\mathrm{D}_{2 / 1}$ in new crystallization systems, as well as better understanding of the dependences of these coefficients on different factors, permits evaluating in a progressively better way the possibilities of the crystallization method in new crystallization systems and more effective control with "external" conditions to achieve higher yields of crystallization purification, enrichment of trace amounts of rare, scattered elements for preparative or analytical purposes. In addition it also helps in improving the growing of single crystals of specific properties or explaining the genesis of some minerals.

\section{References}

Balarew, Chr.; Duhlev R. \& Spassov D. (1984). Hydrated metal halide structures and the HSAB concept, Crystal Res. Technol. Vol. 19(11), pp. 1469

Balarew, Chr. (1987). Mixed crystals and double salts between metal (II) salt hydrates, Zeitschrift fuer Kristallographie., Vol. 181, pp. 35-82

Blamforth, A. W. (1965). Industrial Crystallization, Leonard Hill, London 1965, (Great Britain) England

Borneman-Starinkevich, I. D. (1975) Calculation of the crystallochemical formula as one of the methods for the investigation of minerals, In Izomorfizm Minerallov (Eds. F. V. Chukhrov, B. E. Borutsky \& N. N. Mozgova), pp. 125-33 . Nauka, Moskva

Brown, I. D. (1981). Bond-valence method: an empirical approach to chemical structure and bonding. In Structure and bonding in crystals. (Eds. M. O'Keeffe, A. Nawrotsky) Vol. II, p. 1 - 30. New York: Academic Press 1981

Byrappa, K.; Srikantaswamy, S.; Gopalakrishna G. S. \& Venkatachalapaty V. (1986) Influence of admixtures on the crystallization and morphology of $\mathrm{AlPO}_{4}$ crystals. J. Mater.Sci., Vol. 21, pp. 2202 - 2206

Chlopin, V. G. (1938). The distribution of electrolytes between solid crystals and liquid phase, Trudy Rad. Inst. AN SSSR Vol. 4, pp. 34-79

Chlopin, V. G. (1957). Izbrannye Trudy, (Selected Work) Vol. 6, pp. 173, Izd. AN SSSR, Moskva, Russia

Demirskaya, O. V.; Kislomed A.N.; Velikhov Y.N.; Glushova L. V. \& Vlasova D. I. (1989) Distribution of impurities during crystallization of potassium dihydrophosphate from aqueous solutions at $25^{\circ} \mathrm{C}$. Vysokochistye Veshchestva, Vol. 1, pp. 14-16

Doerner, H. A. \& Hoskins, W. M. (1925). Coprecipitation of radium and barium sulfates, J. Am. Chem. Soc.,Vol.47, pp 662-75

Fisher, S. (1962). Correlation between maximum solid solubility and distribution coefficient for impurities in Ge and Si, J. Appl. Phys., Vol.33, pp 1615

Gorshtein, G. I. (1969). In Methods of obtaining of high-purity inorganic substances (in Russ.), Izd. Chimia, Sanct Petersburg, Russia, (63-125)

Hill, A. E.; Durham, G. S. \& Ricci, J .E. (1940). Distribution of isomorphous salts in solubility equilibrium between liquid and solid phases, J. Am. Chem. Soc., Vol. 62, pp 2723-32 
Kirkova, E. (1994). Vysokochisti Vechtestva - Metodi na poluchavane, Sofia University Press, Sofia

Kirkova, E.; Djarova, M. \& Donkova, B. (1996). Inclusion of isomorphous impurities during crystallization from solutions, Prog. Crystal Growth and Charact., Vol.32, pp 111 -134

Klopman, G. (1968). Chemical reactivity and the concept of charge- and frontier-controlled reaction, J. Am.Chem.Soc. Vol.90, pp. 223-234

Kowalik, A.; Smolik M. \& Mączka K. (2011). The influence of temperature on the values of distribution coefficients $\mathrm{D}_{2 / 1}$ during the crystallization of $\mathrm{CoSeO}_{4} \cdot \mathrm{nH}_{2} \mathrm{O}$, The $1^{\text {st }}$ international conference on methods and materials for separation processes Separation Science - Theory and Practice, Kudowa Zdrój 2011, Poland

Matusievich, L. M. (1961). Influence of diffusion on the process of joint crystallization of isomorphous salts, Zh. Neorg. Khim., Vol.6, pp. 1020-7

Mikheev, N. B.; Mikheeva, L. M.; Malinin, A. B. \& Nikonov, M. D, (1962). Effect of complex formation on the separation of elements by cocrystallization process obeying logarithmic rule, Zh. Neorg. Khim, Vol. 7, pp. 2267-2270

Niesmiejanov, A. N. (1975). Radiochemia, PWN, Warszawa, Poland

Oikova, T.; Balarew, Chr. \& Makarov, L. L. (1976). Thermodynamic study of magnesium sulfate-cobalt sulfate-water and magnesium sulfate-zinc sulfate-water systems at $25{ }^{\circ} \mathrm{C}$, Zh. Fiz. Khim., Vol.50(2), pp. 347-52

Pearson, R . G. (1963). Hard and soft acids and bases, J. Am. Chem. Soc. 85(22), 3533-9

Porterfield, W. W. (1993). Inorganic Chemistry. Unified Approach, Academic Press, Inc. San Diego, New York, Boston, London, Sydney, Tokyo, Toronto,

Przytycka, R. (1968). Coprecipitation of radioactive elements, (in Polish) Wiadomości Chemiczne, Vol. 22, pp. 121-141

Purkayastha, B. C. \& Das, N. R. (1971). Transition temperature of heptahydrated copper sulfate J. Indian Chem. Soc., Vol. 48, pp. 70-4

Purkayastha, B. C. \& Das, N. R. (1972). Study of transition temperature through mixed crystal formation II. J. Indian Chem. Soc., Vol. 49, pp. 245-50

Purkayastha, B. C. \& Das, N. R. (1975). Transition temperature through mixed crystal formation. IV, J. Radioanal. Chem, Vol. 25, pp. 35-46

Ratner, A. P. (1933). Theory of the distribution of electrolytes between a solid crystalline and a liquid phase, J. Chem. Phys., Vol.1, pp 789-94

Ringwood, A. E. (1955). Principles governing trace-element distribution during magmatic crystallization. I. Influence of electronegativity. Geochim. Cosmochim. Acta, Vol. 7, pp. $139-202$

Rojkowski, Z. \& Synowiec, J.(1991). Krystalizacja i krystalizatory, (Crystallization and crystallizers) (in Polish) WNT, ISBN 83-204-1375-3, Warszawa, Poland

Ruff, O.; Ebertt F.\& Luft, F. (1928). Röntgenographic methods for determining substances adsorbed on carbon, Z. anorg. allgem. Chem.,Vol. 170, pp. 49-61

Smolik, M. (1984). Investigations on the method of preparation of high-purity $\mathrm{NiSO}_{4} \cdot 7 \mathrm{H}_{2} \mathrm{O}$, Internal report of the Department of Inorganic Chemistry and Technology, Silesian University of Technology, Gliwice unpublished, (in Polish)

Smolik, M. \& Zołotajkin, M. (1993). Partition of trace amounts of impurities during the crystallization of $\mathrm{CuSO}_{4} .5 \mathrm{H}_{2} \mathrm{O}$, Polish J. Chem. Vol. 67(3), pp. 383-389

Smolik, M, \& Lipowska, B. (1995). Partition of trace amounts of impurities during the crystallization of $\mathrm{FeSO}_{4} .7 \mathrm{H}_{2} \mathrm{O}$ at $20^{\circ} \mathrm{C}$., Indian J. Chem., Vol. $34 \mathrm{~A}$, pp.230-4 
Smolik, M.; Zołotajkin, M. \& Kluczka, J. (1995). Distribution of trace amounts of impurities during manganese (II) sulfate crystallization at $20^{\circ}$ and $2{ }^{\circ} \mathrm{C} .$, Polish J. Chem., Vol.69, pp.1322-7

Smolik, M. (1995a). Cocrystallization of trace amounts of metal ions with $\mathrm{NH}_{4} \mathrm{Fe}\left(\mathrm{SO}_{4}\right)_{2} \cdot 12 \mathrm{H}_{2} \mathrm{O}$, (in Polish) - $5^{\text {th }}$ Symposium "Industrial crystallization" Rudy, Institute of Inorganic chemistry, Gliwice, pp. XVIII (1-8), Poland

Smolik, M. (1995b). Partition of trace amounts of impurities during the crystallization of $\mathrm{NH}_{4} \mathrm{Al}\left(\mathrm{SO}_{4}\right)_{2} \cdot 12 \mathrm{H}_{2} \mathrm{O}$, (in Polish), Scientific Meeting of the Polish Chemical Society, Lublin, Poland

Smolik, M. (1998a). Distribution of cocrystallized microamounts of some $\mathrm{M}^{+}$ions during $\mathrm{NiSO}_{4} \cdot\left(\mathrm{NH}_{4}\right)_{2} \mathrm{SO}_{4} \cdot 6 \mathrm{H}_{2} \mathrm{O}$ crystallization., Acta Chem. Scand., Vol.52, pp 891-6

Smolik, M. (1998b). Cocrystallization of trace amounts of metal ions with $\mathrm{Na}_{2} \mathrm{SO}_{4}$ (in Polish), $6^{\text {th }}$ Symposium "Industrial crystallization" Rudy 1998 (in Polish), Institute of Inorganic chemistry, Gliwice, pp. 91-101

Smolik, M. (1999a). Partition of microamounts of some $\mathrm{M}^{2+}$ ions during $\mathrm{MgSO}_{4} \cdot 7 \mathrm{H}_{2} \mathrm{O}$ crystallization. Austr. J. Chem. Vol. 52, pp. 425-430

Smolik M. (1999b) Distribution of trace amounts of some $\mathrm{M}^{2+}$ ions during nickel chloride crystallization coefficients, Polish J. Chem. Vol.73, pp. 2027-2033

Smolik, M.; (2000a). Distribution of microamounts of some $\mathrm{M}^{2+}$ ions during $\mathrm{ZnSO}_{4} \cdot 7 \mathrm{H}_{2} \mathrm{O}$ crystallization., Canadian J. Chem., Vol.78(7), pp. 993-1002

Smolik, M. (2000b). Distribution of trace amounts of $\mathrm{M}^{2+}$ ions during crystallization of $\mathrm{NiSO}_{4} \cdot 7 \mathrm{H}_{2} \mathrm{O}$, Polish J. Chem., Vol. 74, pp. 1447-1461

Smolik, M. (2001). Distribution of microamounts of $\mathrm{M}^{2+}$ during $\mathrm{NiSO}_{4} \cdot\left(\mathrm{NH}_{4}\right)_{2} \mathrm{SO}_{4} \cdot 6 \mathrm{H}_{2} \mathrm{O}$ crystallization, Separation Science and Technology Vol. 36(13), pp. 2959-2969

Smolik, M. (2002a). Factors influencing cocrystallization coefficients D of trace amounts of $\mathrm{M}^{2+}$ ions in some sulfate crystallization systems $\left(\mathrm{M}^{\prime} \mathrm{SO}_{4} \mathrm{nH}_{2} \mathrm{O}-\mathrm{H}_{2} \mathrm{O}\right), 1^{\text {th }}$ International Symposium on Solubility Phenomena, Varna 2002, Abstract Book, pp.37

Smolik, M. (2002b). Cocrystallization of trace amounts of $\mathrm{M}^{2+}$ ions with $\mathrm{CdSO}_{4} 8 / 3 \mathrm{H}_{2} \mathrm{O}, 10^{\text {th }}$ International Symposium on Solubility Phenomena, Varna 2002, Abstract Book, pp. 93

Smolik, M. (2003). Cocrystallization of low amounts of $\mathrm{M}^{2+}$ ions during $\mathrm{CoSO}_{4} \cdot 7 \mathrm{H}_{2} \mathrm{O}$ crystallization, J. Chilean Chem. Soc.,Vol. 48(3), pp. 13-18

Smolik, M. (2004) (Effect of some chemical, physicochemical and crystal-chemical factors on cocrystallization coefficients $\mathrm{D}_{2 / 1}$ of trace amounts of metal ions during the crystallization of chosen salts from water solutions (in Polish), Zesz. Nauk. Pol. Sl. Chemia, No 1617, Vol. 148, pp 1-186

Smolik, M. Jakóbik, A. \& Trojanowska J. (2007). Distribution of trace amounts of $\mathrm{M}^{2+}$ ions during $\mathrm{Co}\left(\mathrm{CH}_{3} \mathrm{COO}\right)_{2} \bullet 4 \mathrm{H}_{2} \mathrm{O}$ crystallization, Sep. Pur. Techn., Vol. 54, pp. 272-276

Smolik, M. (2008). Effect of chemical, physiochemical and crystal-chemical factors on cocrystallization coefficients of trace amounts of metal ions $\mathrm{M} 2+$ during the crystallization of selected acetates $\mathrm{M}(\mathrm{CH} 3 \mathrm{COO}) 2 \mathrm{nH} 2 \mathrm{O}$, Chemik, Vol.10, pp 526-529

Smolik, M. \& Kowalik, A. (2010). Co-crystallization of trace amounts of $\mathrm{M}^{2+}$ ions with $\mathrm{ZnSeO}_{4} \cdot 6 \mathrm{H}_{2} \mathrm{O}$ at $25^{\circ} \mathrm{C}$, J. Cryst. Growth, Vol. 312, pp, 611- 616

Smolik, M. \& Kowalik, A. (2011a). Equilibrium coefficients of co-crystallization of M2+ ions with $\mathrm{MgSeO} 46 \mathrm{H} 2 \mathrm{O}$ and their dependences on various physicochemical factors, Crystal Research and Technology, Vol. 46, pp. 74-9 
Smolik, M. \& Kowalik, A. (2011b). Coefficients, $\mathrm{D}_{2 / 1}$ of cocrystallization of $\mathrm{M}^{2+}$ ions with $\mathrm{ZnSeO}_{4} \cdot 5 \mathrm{H}_{2} \mathrm{O}$ at $40^{\circ} \mathrm{C}$ and $\mathrm{ZnSeO}_{4} \cdot \mathrm{H}_{2} \mathrm{O}$ at $50{ }^{\circ} \mathrm{C}$ and their dependences on various physicochemical and crystal-chemical factors, J. Cryst. Growth, Vol. 337, pp. 46-51

Smolik, M. \& Siepietowski, L. (2011). Some factors influencing distribution coefficients of trace amounts of $\mathrm{M}^{2+}$ ions during the crystallization of $\mathrm{Mn}\left(\mathrm{CH}_{3} \mathrm{COO}\right)_{2} \cdot 4 \mathrm{H}_{2} \mathrm{O}, S$. Afr. J. Chem., Vol. 64, pp. 34-37

Tepavicharova, S.; Balarew, Chr. \& Trendafilova S. (1995). Double salts obtained from $\mathrm{Me}+\mathrm{X}-\mathrm{CuX} \mathrm{X}_{2}-\mathrm{H}_{2} \mathrm{O}$ systems $\left(\mathrm{Me}+=\mathrm{K}^{+}, \mathrm{NH}^{+}, \mathrm{Rb}^{+}, \mathrm{Cs}^{+} ; \mathrm{X}^{-}=\mathrm{Cl}^{-}, \mathrm{Br}-\right)$, J. Solid State Chem. 114, 385-91

Urusov, V. S. (1970). Energy theory of isovalent isomorphism, Geochimia, Vol. 4, pp. 510-24

Urusov, V. S. \& Kravchuk I. F. (1976). Energy analysis and calculations of partition coefficients of isovalent isomorphous admixtures during crystallization of melts, Geochimia, Vol. 8, pp. 1204-23

Urusov, V. S. (1977). Theory of the Isomorphous Miscibility, Nauka, Moskva, Russia

Urusov, V. S. (1980). Energy formulation of the problem of equilibrium cocrystallization from a water solution, Geochimia, Vol.54, pp. 627-44

Vachobov, A. V.; Khudaiberdiev, V. G. \& Vigdorovich, V. N. (1968). Relation between the distribution coefficient for crystallization purification and the limited solubility of the impurity in the solid state, Dokl. Tadzh. Akad. Nauk, Vol.11(8), pp 19-22

Zhelnin, B. I. \& Gorshtein G. I. (1971). Investigations on equilibrium in the system $\mathrm{MnSO}_{4^{-}}$ $\mathrm{MgSO}_{4}-\mathrm{H}_{2} \mathrm{O}$ at 25 and $100{ }^{\circ} \mathrm{C}, \mathrm{Zh}$. Neorg. Khim. Vol. 16, pp. 3146-50

Zolotov, Yu. A. \& Kuz'min, N. M. (1990). Preconcentration of trace elements, Elsevier, Amsterdam, Oxford, New York, Tokyo 
(C) 2012 The Author(s). Licensee IntechOpen. This is an open access article distributed under the terms of the Creative Commons Attribution 3.0 License, which permits unrestricted use, distribution, and reproduction in any medium, provided the original work is properly cited. 